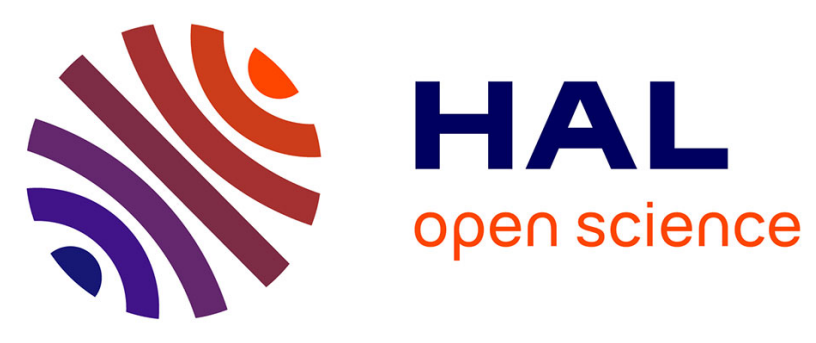

\title{
The missing Myopus: plugging the gaps in Late Pleistocene small mammal identification in western Europe with geometric morphometrics.
}

Louis Arbez, Aurélien Royer, Danielle Schreve, Rémi Laffont, Serge David, Sophie Montuire

\section{To cite this version:}

Louis Arbez, Aurélien Royer, Danielle Schreve, Rémi Laffont, Serge David, et al.. The missing Myopus: plugging the gaps in Late Pleistocene small mammal identification in western Europe with geometric morphometrics.. Journal of Quaternary Science, 2021, 36 (2), pp.224-238. 10.1002/jqs.3269 . hal03161762

\section{HAL Id: hal-03161762 \\ https://hal.science/hal-03161762}

Submitted on 20 Oct 2021

HAL is a multi-disciplinary open access archive for the deposit and dissemination of scientific research documents, whether they are published or not. The documents may come from teaching and research institutions in France or abroad, or from public or private research centers.
L'archive ouverte pluridisciplinaire HAL, est destinée au dépôt et à la diffusion de documents scientifiques de niveau recherche, publiés ou non, émanant des établissements d'enseignement et de recherche français ou étrangers, des laboratoires publics ou privés. 
1 The missing Myopus: plugging the gaps in Late Pleistocene small 2 mammal identification in western Europe with geometric 3 morphometrics

4 Louis Arbez ${ }^{1,2,}$, , Aurélien Royer ${ }^{2}$, Danielle Schreve ${ }^{3}$, Rémi Laffont ${ }^{2}$, Serge David ${ }^{4}$, Sophie 5 Montuire $^{1,2}$

6

$7 \quad{ }^{1}$ EPHE, PSL University, 6 Boulevard Gabriel, 21000 Dijon, France;

$8{ }^{2}$ Biogéosciences, UMR 6282, CNRS, EPHE, Université Bourgogne Franche-Comté, 6 9 Boulevard Gabriel, 21000 Dijon, France;

$10{ }^{3}$ Department of Geography, Royal Holloway University of London, Egham, Surrey TW20 11 0EX, UK;

$12 \quad{ }^{4}$ CJP - Centre Jurassien du Patrimoine, 2, place de l'Hôtel de Ville 39000 Lons-le-Saunier;

$13 \quad{ }^{a}$ Louis.Arbez@u-bourgogne.fr.

14 Abstract word count: 205

15 Main text word count: 7424

16 Figures: 6

17 Tables: 4

18 Bibliography: 3047 words, 104 references

19 Annexes: 1 table 
Lemmus and Myopus are two lemming species with distinct habitat requirements but which show very similar dental morphologies. They are thus extremely difficult to distinguish from one another in the fossil record on the basis of their dental remains, leading to poor understanding of the palaeobiogeographical evolution of Myopus as well as inaccurate paleoenvrionmental reconstructions. Currently, the presence of Myopus in the fossil register from the Pleistocene is still debated and no firm occurrence of this lemming in western Europe has yet been confirmed during the Late Pleistocene. In this paper, we used geometric morphometrics on modern material to establish morphological differences between Lemmus and Myopus teeth (first lower and third upper molars). Morphological data was then used to build a robust linear discriminant model able to confidently classify isolated teeth of these two genera, and finally, linear discriminant models were used on fossil remains of Lemmus/Myopus from two Late Pleistocene archaeological/palaeontological sites (Grotte des Gorges and Gully Cave). This study demonstrates, for the first time, the presence of Myopus schisticolor in west European Late Pleistocene sites between the end of MIS 3 and the beginning of Holocene, during climatic events that favoured the development of taiga forest of birch and pine in these regions.

\section{Keywords}

Geometric morphometrics, Lemming, Late Glacial, Paleobiogeography, Molar shape, Boreal environment, Taxonomy

\section{Introduction}

Rodents are characterized by a significant taxonomic diversity associated with various ecological and biological traits, thereby ensuring their widespread occurrence throughout all modern biotopes. They have been intensively studied with respect to the fields of evolution, 
biochronology and palaeoenvironmental change (e.g. Chaline and Mein, 1979; Cox and Hautier, 2015; Fejfar and Heinrich, 1990; Hernandez Fernandez, 2006; van Kolfschoten, 1995; Kowalski, 1995; Montuire et al., 1997; Rekovets and Kovalchuk, 2017). Their remains, well preserved in many archaeological and palaeontological contexts, have therefore contributed to the reconstruction of patterns of Quaternary palaeoclimatic change, still a major challenge in our understanding of continental chronostratigraphies today. Among the methods applied for paleoclimate reconstructions, many are based on species associations, such as the presence/absence or relative abundance of species, hence the need to have accurate taxonomic identifications (e.g. Gobalet 2001; Lyman, 2002, 2019; Royer et al., 2020; Stahl, 1996).

Numerous obstacles hinder the identification of small-bodied animals, even when their skeletal remains are recovered (Stahl, 1996). One problem is that while modern zoologists have many criteria by which to identify animals (e.g. fur, size, skull and post-cranial anatomy, geographical range), most of these criteria cannot be applied to fossils. A second problem is that identification of small mammals is based on limited types of remains, generally the teeth, which are most resistant to mechanical taphonomical processes. Despite dental remains being the most diagnostic elements at the genus or species levels, teeth may exhibit very similar morphologies, which could potentially prevent confident identifications. The last problem also reflects the differential state of diagnostic information for relevant taxa (Lyman, 2019; Stahl, 1996). Many criteria have been proposed to identify these smallest-size species, but most of them rely on the "holotypic" morphology (i.e. the typical form as defined by characteristic specimens of this species), without taking into account geographical or inter-population variability, except to point out very unusual cases. The ensuing large number of criteria proposed for species identification often leads either to disagreement or to differential use of these criteria among taxonomists. As said by Stahl (1996), it must always be remembered that higher level taxonomic categories are necessarily dynamic and constantly open to revision. 
Among the rodents, voles and lemmings, which show substantial tooth variability throughout species, time and space, are key taxa for tracking Quaternary environmental and climatic changes (e.g. Kowalski, 2001; Montuire et al., 2019; Nadachowski 1982; Royer, 2013). Lemmings are reliable biomarkers of specific and typical high latitude environments (Chaline, 1972; Kowalski, 1995). In Eurasia, four lemming genera are found in fossil contexts: 1) Dicrostonyx and Lagurus, which are regularly present during the coldest or driest phases of the Late Pleistocene extending as far as the south of France (Chaline, 1972; Marquet, 1993; Royer et al., 2016); 2) Lemmus, which is also frequently found throughout Eurasia in open and cold environments, but still in modest abundance (Kowalski, 1995, 2001), and 3) Myopus, which has so far only been attested in Russia at this time, associated with more temperate species (e.g. Markova et al., 2019; Ponomarev et al., 2013a, 2013b, 2013c).

As Lemmus (Link, 1795) and Myopus (Miller, 1910) have two strong but divergent ecological signals, their taxonomic discrimination in the fossil assemblages is essential in order to investigate past faunal associations and understand their significance in paleoclimatic reconstructions. The True Lemming genus (Lemmus) is a complex of several species which have a northern distribution restricted to Arctic tundra environments associated with high seasonality and little vegetation. These taxa use the thick snow covering as a shelter, giving them access to the vegetation persisting under this natural shield during winter (Domine et al., 2018; Reid et al., 2011; Stenseth and Ims, 1993), as well as using bogs and wetlands during summer and eschewing forest as much as possible (Le Vaillant et al., 2018; Wilson et al., 2017). The wood lemming (Myopus schisticolor [Lilljeborg, 1844]) is the only representative of its genus and inhabits exclusively coniferous forest with a thick moss cover, which constitutes its main food source (Bobretsov and Lukyanova, 2017; Calandra et al., 2015; Eskelinen, 2002). Contrary to Lemmus, this taxon avoids bogs and marshes and is present throughout the taiga forests from Scandinavia to the eastern coast of the Sea of Okhotsk. 
Although Myopus and Lemmus are separated by a large phylogenetic distance (Abramson and Petrova, 2018) and are easily distinguishable in their external appearance (Gromov and Polyakov, 1992; Wilson et al., 2017), they express a great deal of similarity in terms of their dental morphology (Borodin, 2009; Chaline et al., 1988; Koenigswald and Martin, 1984; Kowalski, 1995), resulting in their fossil remains often being impossible to separate or being lumped together as "Lemmus-Myopus" (Kowalski, 2001). This problem of differentiation has therefore greatly reduced the palaeoecological utility of these taxa, which is particularly problematic considering their occurrence in many Quaternary deposits. Several authors have accordingly attempted to separate these two genera through morphometrical analysis of the first lower molar (m1) and the third upper molar (M3) but with varying degrees of accuracy (Chaline et al., 1988; Markova et al., 2018; Ponomarev et al., 2013b; Smirnov et al., 1997).

The present paper aims to resolve this problem by providing a robust means of differentiating between the teeth of these two genera, Lemmus and Myopus. This study uses geometric morphometrics, which has never been applied on these two genera, despite its efficiency in identifying similar species in modern and fossil record (e.g. McGuire, 2011; Cucchi et al., 2014; Hulme-Beaman et al., 2018; Stoetzel et al., 2017; Navarro et al., 2018; Kolendrianou et al., 2020). Several modern populations were considered, both to establish differences in their dental morphologies and to evaluate the reliability of traditional criteria previously used to separate the two genera. The geometric morphometric approach is then coupled with a discriminant function analysis in order to separate these two genera before being applied to European fossil specimens from two Late Pleistocene sites. The outcomes of this paper consequently propose not only a novel and replicable means of identifying and separating the two genera, but also allow a new view of the past environments and biogeographical evolution of lemming populations. 


\section{Taxonomy and Morphology}

Lemmus and Myopus genera belong to the tribe Lemmini (Gray, 1825), which is part of the Arvicolinae subfamily (Gray, 1821). The genus Lemmus is currently divided into four distinct species (Abramson and Petrova, 2018; Wilson et al., 2017): the Nearctic North American brown lemming Lemmus trimucronatus (Richardson, 1825) and the Palearctic Norway lemming Lemmus lemmus (Linnaeus, 1758), Siberian lemming Lemmus sibiricus (Kerr, 1792) and the Amur lemming Lemmus amurensis (Vinogradov, 1924). Originally, Myopus was recognized as a member of the genus Lemmus and named as Lemmus schisticolor (Lilljeborg, 1844) due to osteological similarities, such as the general shape of the skull (Ognev, 1948), the convergence of the maxillary tooth rows and the inclination of the mandibular tooth rows (Abramson, 1993). Miller (1910, 1912) separated Myopus from Lemmus, leading to the recognition of Myopus schisticolor, a species characterized by a combination of Lemmus characters (skull and teeth) and vole characters (general body-form and foot structure). Recent DNA studies clearly attest to the separation of these two genera (Abramson and Petrova, 2018; Buzan et al., 2008; Cook et al., 2004; Robovský et al., 2008).

Molars of Lemmus and Myopus are hypsodont with a flat grinding surface and have a prismatic structure composed of alternate triangles and deep re-entrant angles filled with cement (fig. 1). The first lower molar (m1) is constituted by a posterior loop (PL), three closed alternating triangles (T1-T3), two confluent triangles (T4 and T5) and an anterior loop (AL). The third upper molar (M3) shows a similar structure (fig. 1), with an anterior loop, five triangles and a posterior loop (PL). For these two molars, some authors note a high variation in the outer loops (anterior loop for $\mathrm{m} 1$, posterior loop for M3), which exhibit different stages of complexity, with the development of supplementary re-entrant angles on both labial and buccal sides (e.g. Markova et al., 2018; Ponomarev et al., 2013b). In general, Lemmus shows a higher tendency to complexity (i.e. development of supplementary re-entrant angles) and Myopus has a simpler 
morphology. However, due to a large overlap, these trends cannot be used to definitively attribute individuals to one or the other of these genera. Based on biometrical approaches, linear measurements are the most commonly used features to distinguish these two genera on isolated teeth (e.g. Borodin, 2009; Ponomarev et. al., 2013b; Roberts and Parfitt, 1999; Tiunov and Panasenko, 2011), with the following features identified as being of potential significance: 1) differences in the length/width ratio of M3 (Smirnov et al., 1997), with the M3 shape in Myopus tending to be more compact and that in Lemmus tending to be more elongated;2) ratios obtained from several linear measurements to characterize the global shape of the different molars (Chaline et al., 1988); and 3) the size of the teeth, with a greater tooth length in Lemmus (Chaline et al., 1988; Smirnov et al., 1997). Finally, a supplementary criterion based on cementum was recently proposed by Ponomarev et al. (2013b). This last work shows that the frequency of cementum deposits in the last re-entrant angles of the outer loops of both M3 and m1 (LRA3 and BRA4 of m1) differs between the two genera. The cementum deposits are absent in Myopus teeth, whereas they are present in 40 to $70 \%$ of Lemmus individuals (Cheprakov, 2016; Markova et al., 2018; Ponomarev et al., 2013).

\section{Materials and methods}

\subsection{Modern specimens}

Since the focus of this paper is the application of the geometric morphometrics method to western European fossil sites, modern Lemmus and Myориs individuals were targeted from Scandinavia and Russia. The modern samples are composed of research laboratory collections and Snowy Owl (Bubo scandiacus) pellets and are housed in the research laboratory collections in Biogéosciences at the University of Burgundy and in the Arctic Research Station of Labytnangi in Russia. In total, 30 Myopus and 96 Lemmus m1 specimens, and 31 Myopus and 91 Lemmus M3 specimens were analysed (see table 1 for details). Since the Myopus genus is monospecific, our sample was only composed of individuals of Myopus schisticolor. To 
describe most of the current morphological variability of the Lemmus genus, our sample included specimens from the three different species. Most of our sample belong to two palearctic species, with 50 Norway Lemming (L. lemmus) and 34 western Siberian Lemming (L. sibiricus). The two species are closely related in their phylogeny but were already separated during the Late Pleistocene (Abramson and Petrova, 2018). Few individuals of eastern $L$. sibiricus from Chukotka district were included to capture the range of potential variability of the genus. Additionally, $12 \mathrm{~m} 1$ and $8 \mathrm{M} 3$ of North American Brown Lemming ( $L$. trimucronatus) were included to clarify the distinction amongst the different representatives of Lemmus. Numbers and origins of the specimens are detailed in table 1 and figure 2. Only wellpreserved and complete molars were used in the analyses; all broken and digested teeth were discarded.

\subsection{Fossil samples}

Fossil specimens come from two archaeological/palaeontological sites from Late Pleistocene, la Grotte des Gorges (France) and Gully Cave (England) (fig. 2). As for the modern material, broken and digested teeth were not included in this study. All dates of la Grotte des Gorges have been calibrated using IntCal13 (Reimer et al., 2013).

La Grotte des Gorges is located close to Amange village (Jura, France) and was excavated between 2008 and 2017. Two layers (1a and 1b) yielded archaeological material (David et al., 2014, 2017), from the end of MIS 3 with AMS dates ranging from 33,030 \pm 750 to $29,390 \pm$ 170 uncal. BP. The site yields a diverse association of mammalian species demonstrating a transition from arctic toward steppe environment. Lemmus/Myopus remains come from the upper part of the sequence (layer 1a), dominated by typical taxa of cold-climate phases such as reindeer (Rangifer tarandus), mammoth (Mammuthus primigenius), rhinoceros (Rhinocerotidae) and collared lemmings (Dicrostonyx torquatus) The second phase of the sequence (layer 1b) is dominated by bison (Bison priscus), which is typical taxa of steppe 
environment. A total of 11 first lower and 3 third upper molars attributed to Lemmus/Myopus has been analysed (table 1 and figure 2).

Gully Cave is located in Ebbor Gorge (Somerset, UK) and has been the subject of ongoing excavation since 2006. The upper stratigraphic units (of relevance here) consist of matrix-rich limestone breccias of Lateglacial Interstadial and Holocene age respectively, separated by a coarse, open-framework limestone breccia deposited during the Younger Dryas, the stratigraphy underpinned by radiocarbon dates on mammalian faunal remains from throughout the sequence. The cave was completely filled by around 10,000 cal years BP and the sequence was capped by a discontinuous flowstone. A total of $35 \mathrm{~m} 1$ teeth were analyzed, 12 from the Younger Dryas levels (date range 12409-12037 cal. BP to 11950-11259 cal. BP) and the other 23 from the boundary level between the Allerød interstadial and the Younger Dryas (date range 12379-12637 cal. BP to 13214-13444 cal. BP), and 43 M3s, with 17 from the Younger Dryas and 26 from the Allerød interstadial-Younger Dryas transition. The mammalian assemblage from the Younger Dryas levels sampled here includes Lepus timidus, Myodes sp., Dicrostonyx torquatus, Lemmus/Myopus, Microtus agrestis or arvalis, Lasiopodomys gregalis, Alexandromys oeconomus, Vulpes sp. and Rangifer tarandus. The sample from the Allerød interstadial-Younger Dryas transition has yielded L. timidus, Ochotona pusilla, Arvicola amphibius, Clethrionomys glareolus, D. torquatus, Lemmus/Myopus, M. agrestis or arvalis, L. gregalis, Al. oeconomus, V. lagopus, $R$. tarandus and Cervus elaphus.

\subsection{Landmark schemes and data acquisition}

All teeth were photographed using a macro objective (Canon EOS6D mark II, macroscopic objective MP-E $65 \mathrm{~mm} \mathrm{f/2.8)} \mathrm{and} \mathrm{saved} \mathrm{in} \mathrm{.jpg} \mathrm{format} \mathrm{with} \mathrm{a} \mathrm{72-dpi} \mathrm{resolution.} \mathrm{To} \mathrm{avoid}$ between-picture deformation, all specimens were photographed one by one with the same distance from the objective and with the same focus. Outlines were then extracted from pictures using ImageJ v.1.52a. The $\mathrm{m} 1$ outline was then orientated with a manual marking of two 
landmarks (Lm 3 and 7, fig. 1), which define the tooth's vertical axis, in order to correctly position the tooth following the protocol of Navarro et al. (2018). No satisfactory orientation could be obtained with this protocol on the M3, so the procedure was adapted as follows. The outline pixels were rotated along the first principal component axis of the outline pixel coordinate matrix. These standardized orientations then enabled landmarks located at the extreme tips of the salient and reentrant triangles to be automatically detected, as well as those at the extreme tips of the posterior and anterior loops. All landmarked teeth were further inspected for gross error, and the entire procedure was performed by a single operator, thereby avoiding inter-operator biases.

In total, seven landmark schemes and two biometric measurements were defined to describe the morphological variability of the $\mathrm{m} 1$ and M3 (table 2 and fig.1). The global shape of each tooth was analysed with a fixed landmark scheme (FL), using 14 landmarks for the m1 (m1FL) and 11 landmarks for the M3 (M3-FL). A total of 20 semi-landmarks for m1 and 50 semilandmarks for M3 were used to characterize the outer loops (anterior loop dataset $\mathbf{m 1 - A L}$ and posterior loop dataset M3-PL). The SL schemes, m1-SL and M3-SL correspond to FL datasets combined with semi-landmarks of outer loops (m1-AL or M3-PL). Another semi-landmark scheme describes the alternation between T2 and T3 of M3 (M3-TR) by using a total of 4 fixed landmarks and 30 semi-landmarks. In all semi-landmark configurations, few fixed landmarks were removed to treat whole loops only using semi-landmarks (landmark removed for each dataset: m1-SL/AL: Lm8, 9, 10; M3-SL/PL: Lm 9, M3-TR: Lm3).

In addition, the tooth length (TL) of the two teeth was estimated based on the Euclidean distance between the most anterior and posterior landmarks (Lm1 and 9 for $\mathrm{m} 1$; $\mathrm{Lm} 1$ and 7 for M3).

\subsection{Geometric morphometrics}

All configurations of each landmark dataset (m1-FL, m1-SL, m1-AL, M3-FL, M3-SL, M3PL, M3-TR) were superimposed using partial Generalized Procrustes Analysis (GPA), 
performed independently for each dataset. This procedure aims to separate the shape component

244 from the position, size and orientation components contained within the coordinates of

245 landmark configurations. GPA proceeds by 1) translating each individual configuration so that

246 their centroids coincide, 2) scaling each landmark configuration to unit centroid size, and 3)

247 rotating each configuration onto the dataset mean shape by minimizing Procrustes distances

248 between each configuration and this mean shape (Dryden and Mardia, 1998; Rohlf and Slice,

249 1990; Zelditch et al., 2012). For m1-SL, m1-AL, M3-SL, M3-PL and M3-TR, semi-landmarks

250 are allowed to slide to minimize the bending energy between the specimen configurations and

251 the meanshape of the dataset under consideration (Bookstein, 1997).

252 The obtained coordinates (Procrustes coordinates) were then projected onto the Euclidean

253 tangent space (the tangent point being the mean shape of the dataset). These tangent space

254 coordinates are finally rotated by a Principal Component Analysis (PCA) to keep only principal

255 components with non-null eigenvalues (the rank deficient nature of tangent space data resulting

256 from loss of degree of freedom during GPA, and, in our case, to some datasets with fewer

257 individuals than shape variables). For each dataset, a few outliers were identified as those

258 individuals with high Procrustes distances compared to their mean shape (i.e. lying beyond the

259 third quartile increased by 1.5 times the interquartile range) and were sequentially removed

260 after a new GPA (table 2).

261 In order to avoid any influence of fossil specimens on the molar shape variation depicted by the

262 tangent space, which was then used to build the discriminant model among both genera, we

263 treated fossil specimens as supplementary specimens in our analyses (see Navarro et al. 2018).

264 Fossil specimens were so aligned on the modern mean shape so that, for a given dataset, they

265 lay on the same shape and tangent spaces as the modern individuals. Then, the rotation

266 computed on the tangent space for the modern individuals was used to rotate the projection of

267 fossil specimens in the same way. 
All geometric morphometrics analyses were performed with the geomorph package version 3.2.0 on R v3.6.2 (R Core team, 2019).

270

271

272

\subsection{Statistical classification}

The predictive model was built using linear discriminant analysis (LDA) quantifying the shape differences between the two genera (Myopus vs Lemmus), and the quality of the obtained model was assessed by Leave-One-Out Cross-Validation (LOOCV). This procedure removes one specimen from the sample at a time and predicts its classification between groups using LDA functions calculated on the remaining specimens. Then, the removed specimen is classified by a new function, computed using data that do not take the specimen into consideration, thereby reducing potential inflation of the prediction error and avoiding issues of circular reasoning and over-fitting problems (Kovarovich et al., 2011).

LDA can be extremely sensitive to the relation between the number of groups, the number of predictor variables and the total sample size. As rule-of-thumb, the total number of predictor variables needs to be smaller than the sample size of the smallest predicted group (Kovarovich et al., 2011). Special attention has been paid to this rule due to our small sample size and the high number of predictor variables. Firstly, we reduced the number of predictors used to build the discriminant functions by applying the method of Baylac and Friess (2005). This method substitutes primary data (Procrustes coordinates) by PCs scores to build the model. This was done by building each model and its LOOCV based on the first $k$ PCs, with $k$ varying from 1 to $p$ ( $p$ being the sample size of the smallest group under consideration). The optimal number of PCs for the most efficient model was determined by the lowest prediction error rate (i.e. the maximum number of correctly assigned specimens).

Secondly, the method of Evin et al. (2013) was used to evaluate possible biases due to our unbalanced dataset. For a given unbalanced dataset, 100 balanced samples were built by randomly picking a subset of individuals from the largest group, and for each such sample, 
LDA was computed. The observed classification score for each unbalanced dataset was then compared with these 100 balanced samples. Models were also compared with the null hypothesis of no shape difference between genera (hence the classification would be only due to chance, resulting in a $50 \%$ error rate). 100 such null models were generated for balanced samples of the two species by randomly reassigning specimens to genera. Finally, the quality of the models was evaluated by checking at posterior probabilities of correctly assigned genus for each dataset.

All codes including automatic landmark placement and data treatment are available on request.

\section{Results}

4.1. Morphospaces and morphological variation

\subsubsection{The first lower molar}

In the tooth shape analyses (m1-FL, m1-SL and m1-AL), the two first PCs account, respectively, for $32.6 \%, 56.6 \%$ and $69.6 \%$ of the explained variance (table 3, fig. 3 ). The number of PCs explaining at least $90 \%$ of the initial shape variation is 13,12 and 6 , respectively. For the m1-FL configuration, shape changes mainly concern the buccal triangles (T2-T4) shifting labially and the Lm1 and 9 shifting laterally. For the m1-SL, the main behaviour is focused on the anterior loop, which tends to roundness enhancing the confluence of T4/T5 (fig. 3B). The shape variation on $\mathbf{m} \mathbf{1}-\mathbf{A L}$ exhibits a more pronounced development of the re-entrant angles (fig. 3C). The most important part of the variation is expressed by PC1 and tends to separate the two genera for all datasets, with the least overlap for the m1-SL analysis and the largest one for the m1-FL (fig. 3A). On the two first PCs from these three landmark schemes, one can note no specific distinction between Lemmus species (fig. 3). The tooth lengths of Lemmus and Myopus range from 1.6 to $2.4 \mathrm{~mm}$ and from 1.4 to $1.7 \mathrm{~mm}$, respectively (fig. $3 \mathrm{H}$ ).

A large overlap in the tooth length range is observed between the two genera, with $86 \%$ of the 
Myopus specimens being included within Lemmus's tooth length range. Within the Lemmus genus, L. sibiricus is the species which has the longest tooth length compared to the two others.

\subsubsection{The third upper molar}

The same pattern as $\mathrm{m} 1$ is observed on the M3 with the first two PCs explaining 46.1\%, 70.0\%, 75.7\% and 57.7\% of variation respectively M3-FL, M3-SL, M3-PL and M3-TR (table 3, fig. 3). The number of PCs explaining at least $90 \%$ of the initial shape variation is $10,8,5$ and 6 , respectively. The shape variation illustrated by PC1 for M3-FL concerns the width and length of the teeth, with a tendency to be more "compact" (i.e. thinner and smaller) (fig. 3D). For M3SL, the main changes occur on the lingual triangles and anterior loop, with an enlargement on the lingual side (fig. 3E). Similar changes on the posterior loop are also observed on M3-PL. The first PC of M3-TR describes the T3/T4 alternation, with a T3 tending to close. As for m1, the PC1 tends to separate the two genera, with least overlap for the M3-SL analysis and the largest overlap for the M3-TR for which no separation is observed between the two genera (fig. 3G). Again, the two first PCs do not show any clear difference between Lemmus species across all landmark schemes. The M3 tooth lengths follow the same pattern as for m1 with a large overlap between the two genera. Lemmus range from 1.2 to $1.8 \mathrm{~mm}$ and Myopus from 1.0 to $1.4 \mathrm{~mm}$, with $90 \%$ of M. schisticolor being included in the Lemmus tooth length interval (fig. $3 I)$.

\subsection{Statistical classification of modern specimens and shape differences}

Although there was only a relatively small number of individuals from Myopus (the smallest sample), the unbalanced prediction error curves of the landmark schemes do not show particular bias compared to the balanced ones (fig. 4a). Nonetheless, a bias was noted between the dimensionality of the predictor (the number of PCs included to build the LDA) and the prediction error, with an increase when a high number of predictors is used (fig. 4a). This pattern could be due to the small size of the model samples in relation to the large dimensionality of 
the shape space, as encountered by Evin et al. (2013). It is likely that with a larger dataset, such as that presented by Navarro et al. (2018), this pattern would not be observed. The optimal number of predictors (PCs), i.e the one giving the lowest prediction error rate, was selected to build the discriminant functions of the models and are detailed in table 3. Six models (m1-FL, m1-SL, m1-AL, M3-FL, M3-SL and M3-PL) have low prediction errors inferior to 5\% for unbalanced samples (the real samples). Models of the $\mathrm{m} 1$ tend to have a lower prediction error compared to those from the M3 (fig. 4b; table 3). Landmark schemes of the $\mathrm{m} 1$ taking in account the anterior loop (m1-SL and $\mathbf{m 1 - A L})$ give the best classifications, up to 0.96 and 0.93 . The same pattern is visible on the M3 and the posterior loop, with M3-SL having 0.95 optimal classification score, with M3-FL and M3-PL having comparable scores of 0.89 and 0.88 . In contrast, the tooth length (m1-TL and M3-TL) has very low classification scores, with 0.41 and 0.42 respectively, which is comparable to a classification only due to chance.

Figure 5 illustrates the shape differences between Lemmus and Myopus for modern individuals along the first discriminant axis from the LDA regarding the different landmark schemes. In terms of the $\mathrm{m} 1$ shape, Myopus tends to differ from Lemmus with: 1) a different orientation of the lingual triangles, tending to sweep upwards; 2) a simpler anterior loop with a less marked labial peak; and 3) a LRA3 that extends less deeply over the BRA2 without generating a new re-entrant angle on the buccal side of the anterior loop. For the M3, Myopus tends to differ from Lemmus as follows: 1) an overall stockier tooth; 2) a simpler posterior loop, almost flat; and 3) a shorter distance between Lm2 and Lm8. For m1 and M3, tooth lengths show a large overlap with almost all Myopus plotting with the smaller Lemmus specimens.

\subsection{Fossil identifications}

The best performing model (m1-SL) obtained with modern specimens allows the identification of at least one Myopus individual in Grotte des Gorges and one in Gully Cave from the Allerød interstadial-Younger-Dryas transition level, with posterior probabilities at 0.998 and 0.935 , 
respectively (table 4, figure 6a). For these two individuals, similar attributions to Myopus were obtained with other models (m1-FL, m1-AL) (see supplementary table A). The m1-TL model (table 4, figure 6b) cannot attribute any individuals as a Myopus with significant posterior probabilities and only 9 individuals are confidently identified as Lemmus. Most of the specimens are undetermined.

For the M3 (table 4, figure 6c), one tooth has been attributed to Myopus at Gully Cave for the same level, with the best model (M3-SL) giving 0.994 of posterior probability. This attribution was equally obtained with M3-FL and M3-PL models. No model suggests the presence of Myopus in the M3 sample from Grotte des Gorges, but only three teeth were analysed. As for m1-TL, the M3-TL model cannot attribute any individual to Myopus with high posterior probabilities (figure 6d), and the model is unable to confidently identify a large majority of the specimens (table 4, figure 6).

\section{Discussion}

Myopus schisticolor and Lemmus sp. are two lemmings that are currently widespread throughout north Eurasia. They have two distinct habitat preferences, the first inhabits exclusively taiga forest, whereas the second prefers an open tundra environment (e.g. MitchellJones et al., 1999; Niethammer and Krapp, 1982). They both consume mosses, but with variable seasonal proportions: the diet of Myopus schisticolor is restricted only to this vegetation type, whereas Lemmus sp. diversifies its diet during spring and summer with dicots, grasses and sedges being consumed (e.g Batzli and Pitelka, 1983; Calandra et al., 2015; Eskelinen, 2002; Rodger and Lewis, 1986). If distinguishing between these two species is relatively easy at the present day, due to their distinctive external morphology, they are extremely difficult to identify with fossil material, on account of their similar tooth morphologies.

\subsection{Molar shape differentiation}


Despite the similarity in tooth morphology of these two lemming genera, the geometric morphometric approach used in this paper has been able to describe and quantify intergeneric shape differentiation of the first lower molar (m1) and the third upper molar (M3) of modern specimens. Describing the whole shape of the molars with a set of landmarks associated with semi-landmarks on the anterior loop of $\mathrm{m} 1$ or posterior loop of M3 (m1-SL and M3-SL) appears to be the best landmark scheme among those tested here for the modern reference framework. These two landmark schemes have allowed us to separate the two genera with high statistical probabilities, around 0.95 confidence (table 3 ).

These landmark schemes suggest that the main differences between these two genera relate to the tooth complexity with the outer loops more developed in Lemmus than in Myopus. The anterior loop on the $\mathrm{m} 1$ or the posterior loop on the $\mathrm{M} 3$ tend to exhibit a supplementary angle, which is not observed in Myopus. For Myopus, teeth tend to be stockier and simpler in shape. This increased complexity of the anterior $\mathrm{m} 1$ loop in Lemmus, always absent in Myopus, and the organisation of the buccal triangles shifting anteriorly on Lemmus, are congruent with the taxonomic literature (Chaline et al., 1988; Markova et al., 2018; Smirnov et al., 1997; Ponomarev et al., 2013b). Some of these authors also noted that on the M3, the T3/T4 alternation and asymmetry could be used to distinguish both genera. The morphometrical approach developed in this paper thus offered the opportunity to evaluate these criteria (M3TR). Despite the relevance of these criteria, we demonstrate here that they cannot be used to clearly differentiate the two genera because of a large overlap in their morphology (figure 3; table 3).

Among the external morphological criteria allowing differentiation between these two genera, their differences in sizes have been regularly mentioned, with Myopus being smaller (Borodin, 2009). This criterion was often applied to fossil material through measurement of the length of the teeth or dental row (e.g. Borodin, 2009; Kowalski, 1977; Rhodes et al., 2018). Nonetheless, 
as illustrated in figure 3, there is a high overlap between the two genera in terms of tooth length. This overlap is mainly observed between M. schisticolor and L. lemmus, whereas L. sibiricus teeth are taller, with a clear separation from other lemmings (figure $3 \mathrm{H}, \mathrm{I}$ ). Applying the criterion of size to Western European fossil assemblages with lemmings is therefore likely to conflate L. lemmus and M. schisticolor, affirming presence of the former but obscuring the presence of the latter. In any case, size always has to be used very cautiously on fossil species because it can be highly variable according to the time period, the climate or even the latitude and altitude (e.g. Delpech, 1999; Klein, 1986, Klein and Scott, 1989).

By its ability to capture the whole geometry of an object, geometrics morphometrics has therefore become increasingly popular in archaeological and palaeontological studies (e.g. Cucchi et al., 2014; Escudé et al., 2008; Evin et al., 2013; Killick., 2012; Marr, 2016; McGuire, 2011; Miele et al., 2020; Navarro et al., 2018). Associated with classification analysis, such as a LDA, it is a powerful approach that allows differentiation of morphologically close species, thereby assisting in the robust identification of fossil remains and in our understanding of changing faunal communities.

\subsection{Myopus fossil identifications: palaeobiogeographical implications}

During Late Pleistocene glaciations, cold environmental conditions were favourable to lemmings and facilitated their dispersal throughout a large part of Europe (Markova et al., 2019; Royer, 2013), from the Urals (Ponomarev et. al., 2013) to Ireland (Monaghan, 2017; Sutcliffe and Kowalski, 1976; Woodman et al., 1996), including for example France (Marquet, 1993; Royer et al., 2016), Denmark (Bennike et al., 1994; Larsen and Mangerud, 1990) or Czechoslovakia (Horacek and Sanchez-Marco, 1984). Until the present paper, the presence of Myopus in Western Europe was either not envisaged at all or, at best, still questioned. Our results attest its presence in two sites from two distinct periods of Late Pleistocene: la Grotte des Gorges, located in East of France, which is from the end of MIS 3, around $30 \mathrm{ka} \mathrm{cal} \mathrm{BP,}$ 
and Gully Cave, situated in the Somerset (England), from the Allerød interstadial - Younger

442 Dryas transition level.

443 Occurrences of M. schisticolor have already been suggested for European Early and Middle 444 Pleistocene site at Boxgrove (England, Roberts and Parfitt, 1999) and Vergranne (France, 445 Chaline et al., 1989) and suspicions of its presence (records of Myopus/Lemmus) have raised in 446 Chlum-4 (Czech Republic, Kowalski, 2001), Nyaravai-2 (Lithuania, Kowalski, 2001), and 447 Sudmer-Berg 2 (Germany, von Koenigswald, 1972). In general, these suspicions are based on both the morphology of the teeth and on the faunal associations, which are characteristic of a forest environment. However, these tentative suggestions were not uniformly accepted (van Kolfschoten, 1995; 1996; Kowalski, 1995, 2001); for example at Vergranne, Kowalski (1995) stated that the Myopus identification cannot be accepted as definitive. His opinion was that it is not possible to separate Lemmus and Myopus in the fossil record, and that Myopus did not reach Europe during Pleistocene (Kowalski, 2001). Approaches as geometric morphometrics or ancient DNA, which provide reliable identification, imply reconsidering certain determinations based on presuppositions of past studies (geographical area, morphological features, faunal assemblages). The same issues were recently underlined for other species as for example Sorex, with the identification of the boreal Sorex tundrensis in Germany during the end of MIS3 (Freund, 1998; Prost et al., 2013), a species that was not supposed to reach Europe.

Lemming specimens from older Early and Middle Pleistocene sites are generally assigned to 460 ancestral forms of Lemmus, possibly Lemmus kowalskii. This extinct species is then assumed to have lived under temperate conditions in a more wooded environment, as suggested by the forest taxa with which it was associated (van Kolfschoten, 1995; 1996; Kowalski, 1995; 2001). However, identification of Lemmus kowalskii is highly controversial, since it is morphologically similar to Myopus, but much closer in size to Lemmus (Harrison et al., 1989). 
For the Late Pleistocene, several studies attest the presence of Myopus in the Ural (Ponomarev et al., 2013a, b, c) by using the ratios of Smirnov et al. (1997) or morphotype differentiation associated with non-metric multidimensional scaling (Ponomarev et al., 2013a, c). In Europe, Lemmus / Myopus remains from this period are always identified as Lemmus (Lemmus lemmus in the western part of Europe and Lemmus sibiricus in the eastern part). To our knowledge, only one previous occurrence of Myopus schisticolor has been suggested for this period in western part of Europe, in Level 4 of King Arthur's Cave (Wye Valley, England) (Price, 2003), which has been attributed to the Bølling-Allerød interstadial (Bronk Ramsey, 2002). Nevertheless, these determinations (obtained on 12 teeth from a total sample of 17) were only based on tooth length (Price, 2003) and were not corroborated by another approach, although the presence of boreal species in the same level, such as Clethrionomys rufocanus, tends to strengthen this hypothesis (Price, 2003). The identification of Myopus in the Allerød - interstadial layer of Gully Cave corroborates Price's suppositions, suggesting the presence of this species during milder climatic phases in the southern part of England. This presence throughout the septentrional region of Western Europe (i.e. latitude $>45^{\circ} \mathrm{N}$ ) during the Late Pleistocene, raises the question of whether its occurrence was (semi)continuous, or sporadic related to specific climatic events favouring its expansion from eastern regions.

\subsection{Palaeoenvironmental implications of Myopus occurrence in Late Pleistocene}

Since Myopus is today closely linked to the taiga, its identification has strong implications for palaeoenvironmental reconstructions, suggesting past local environments with boreal forest cover mainly composed of Pinus, Betula and Picea, which is favourable to the development of the thick moss cover that constitutes nearly all of its diet (Bobretsov and Lukyanova, 2017; Eskelinen, 2002). Our results from both sites (Grotte des Gorges and Gully Cave) suggest the association of individuals from both genera Lemmus and Myopus. While this might appear contradictory due to their distinct environmental preferences, they were found within a 
diversified faunal association, including for instance Dicrostonyx torquatus, Alexandromys oeconomus or Lasiopodomys gregalis. Although these fossil faunal communities are 'disharmonious' by comparison to present-day small mammal associations and might therefore reflect a palimpsest of distinct phases, the stratigaphical integrity of our study samples is clear. It is therefore more likely that these diverse assemblages reflect the mosaic environment of boreal forest and steppes that are increasingly recognised as typical of the Late Pleistocene of northern Europe.

Multi-proxy investigations on sediment archives have demonstrated continental vegetation to be highly sensitive to Dansgaard-Oeschger events (Fletcher et al., 2010), consequently impacting small mammal communities. Pollen from the Bergsee lacustrine record in Germany demonstrates a high frequency succession of steppe and boreal forest phases, consistent with stadial-interstadial oscillations, and underpinned by increases in Juniperus and Pinus pollen during Greenland Interstadials 8 and 7 (Becker et al., 2006; Duprat-Oualid et al., 2017). The presence of Myopus in la Grotte des Gorges could therefore be related to one of these Greenland Interstadial events.

For Gully Cave, two levels have been investigated, one attributed to the Allerød interstadial Younger Dryas transition, and one from the Younger Dryas. Among individuals from the older level, at least two teeth suggest the presence of $M$. schisticolor according to the most efficient models (m1-SL: 1, M3-SL: 1), but for the cold-climate level of Younger Dryas, no specimens have been attributed to M. schisticolor. Vegetation in Britain was highly sensitive through Late Glacial stadials and interstadials, with regional variation depending of the latitude (e.g. Birks and Birks, 2014; Huntley and Birks, 1983; Jones and Keen, 2012; Pennington, 1977; Walker et al., 2003). In southern England, the Allerød interstadial was a temperate-climate phase characterized by an increase in forest taxa (Hill et al., 2007; Walker et al., 2003), in particular the spread of Betula (Birks and Birks, 2014). The development of this semi-open boreal 
environment in southwestern England (Hills et al., 2007) is echoed by the apparent

516 disappearance of Equus ferus at this time (Kaagan, 2000), and favoured the coexistence of both arctic and boreal species, such as Cervus elaphus and Rangifer tarandus in Cheddar Gorge (Currant and Jacobi, 2011). King Arthur's Cave, which is located $80 \mathrm{~km}$ north of Gully Cave, has equally yielded both forested and cold-adapted taxa (e.g. Dicrostonyx torquatus, Alexandromys oeconomus, Lasiopodomys gregalis, Clethrionomys rufocanus, Microtus agrestis, Lemmus lemmus; Price, 2003), suggesting a mosaic environment. This environment was able to support both Lemmus and Myopus populations during the Allerød interstadial, with the presence of both open and forested areas. The abruptness of the succeeding Younger Dryas cooling event led to drastic vegetation changes, with a decline in forested environments, a decrease in Betula, and a rise of Artemisia in southern England (Birks and Birks, 2014). European Betula macrofossils from this period only belong to Betula nana (Birks and Birks, 2014), reflecting the reduction of forest and inhibiting the development of the moss cover needed by Myopus.

\section{Conclusion}

Our results highlight that: i) the presence of Myopus schisticolor is confirmed for the first time in the Late Pleistocene fossil record of western Europe, although it remains to be established whether its occurrence was (semi)continuous or sporadic, only related to specific climatic events favouring its expansion from eastern regions; ii) its presence has important consequences for palaeoenvironmental interpretations, implying the existence of boreal open/semi open environments.

\section{Author contributions}

Conceptualization, L.A., S.M. and A.R.; Methodology and Software, L.A. and R.L.; Formal analysis, Investigations and Data Curation, L.A.; Validation: R.L.; Resources, S.M., D.S. and 
S.D.; Writing original draft preparation and Visualisation, L.A., S.M. and A.R.; Writing, Review and Editing, L.A., S.M., A.R., D.S., R.L. and S.D.

\section{Acknowledgments}

This study was partially supported by the project HARCGLOB (AAP 2020 Région Bourgogne Franche-Comté). The authors thank Olivier Gilg for giving access to specimens from Victoria Island. We also thank Jérôme Thomas and ReColNat for giving access to the lemming specimens housed at Biogeosciences Palaeontology collection, as well as Aleksandr Sokolov and Natalia Sokolova of the Ural branch of Russian Science Academy for their loan of Siberian lemming's specimens. Danielle Schreve acknowledges the support of the National Trust and Natural England in the excavation of Gully Cave.

\section{Figure captions}

Figure 1: Landmark schemes (in grey squares) defined for Lemmini first lower molar (m1) and third upper molar (M3). Hand-placed landmarks are in white, automatically detected landmarks are in black, and semi-landmarks are in blue (for m1-SL, m1-AL, M3-SL and M3-AL) and in yellow (for M3-TR). Abbreviations: $\mathrm{T}=$ triangles, LRA = lingual re-entrant angles, BRA = buccal re-entrant angles, $\mathrm{AL}=$ anterior loop, $\mathrm{PL}=$ posterior loop. Modified after van der Meulen (1973).

Figure 2: A) Global climate evolution and chronology of the last part of the last glacial following the NGRIP-ice record (Andersen et al., 2004) with the position of the two fossil sites. Abbreviations: MIS: marine isotope stage, HE: Heinrich events, LGM: last glacial maximum, BA: Bølling - Allerød interstadial, YD: Younger-Dryas. B) Geographical range of Lemmus lemmus (blue), Lemmus sibiricus (red) and Myopus schisticolor (yellow) with the overlap area (orange). Circles indicate the location of the modern samples and squares (brown) the localisation of the fossil samples. Site number: 1. Karigasniemi, 2. Kilpisjärvi, 3. PällasjarviMuonio, 4. Rovaniemi, 5. Sabetta, 6. Erkuta, 7. Bely Island, 10. Sotkamo area, 11. Posio, 12. 
Grotte des Gorges, 13. Gully Cave. Localities from North America and Eastern Siberia are not shown (see text for detail).

Figure 3: Morphospaces (PC1 - PC2 planes) of modern specimens with associated shape variation for all landmark schemes (A: m1-FL; B: m1-SL; C: m1-AL; D: M3-FL; E: M3-SL; F: M3-PL) and violin plots for tooth length (H: m1-TL; I: M3-TL). For PCA, displayed shape variation corresponds to morphological changes along the 1st PC axis, depicted by lollipop graphs (grey outline and black dots for the mean shape, black segments for the shape deviation from the mean shape to the most distant individual score on the considered PC). Percentage of shape variation explained by each PC are reported. Myopus are in yellow, Lemmus lemmus in blue, Lemmus sibiricus in red and Lemmus trimucronatus in cyan.

Figure 4: A) Variation of the LDA's prediction error according to the number of PCs included to build the model for each landmark scheme, with $\mathrm{m} 1$ on the left and M3 on the right. For each plot, continuous coloured lines show the prediction error for the original samples, dotted coloured lines show the prediction error for the set of 100 balanced samples, and the grey line show the prediction error for the set of 100 randomly reassigned samples with the associated error bars standing for the $95 \%$ confidence intervals (null hypothesis). B) Model prediction error with the optimal number of PCs for each landmark scheme. Coloured points correspond to the observed prediction error on the real datasets, black points correspond to the prediction error for the set of 100 balanced samples with the associated $95 \%$ confidence interval, grey points show the prediction error for the set of 100 randomly reassigned samples with the associated error bars standing for the $95 \%$ confidence interval (null hypothesis).

Figure 5: Distribution histograms of the modern samples along the linear discriminant axis with associated shape changes. Lemmus are in blue, Mуориs are in yellow. The displayed shapes correspond to the extreme individual scores on the discriminant axis for each landmark scheme.

Figure 6: Distribution histograms of the fossil samples along the discriminant axis from the model based on modern samples for m1-SL, m1-TL, M3-SL and M3-TL datasets. Fossil samples are reported by archaeological/palaeontological levels (scatter plot). Lemmus are in blue, Myopus are in yellow. 
Table captions

Table 1: List of the analysed specimens with their origin and counts (neighbour localities are merged). See figure 1 for localities.

Table 2: Datasets used in the present study. FL $=$ Fixed landmarks, $\mathrm{SL}=\mathrm{Semi}$ landmarks (including FL and $\mathrm{AL}$ for $\mathrm{m} 1$ and FL and PL for M3), PL = Posterior loop, $\mathrm{AL}=$ Anterior loop, $\mathrm{TL}=$ ToothLength .

Table 3: Abbreviations: Tot. PCSs= Total Number of PCs, Opt. PCs = Optimal Number of PCs used in the model, $\mathrm{PC} 1+\mathrm{PC} 2$ = cumulative proportion of variance explained by PC1 + PC2, \% Opt. class. actual $=$ percentage of prediction error of modern specimens with the optimal number of PCs.

Table 4: Fossil identification for $\mathrm{m} 1$ and M3. The number of specimens identified with associated posterior probabilities $>0.9$ are in brackets

\section{Supplementary data captions}

Supplementary table 1: classification of fossil specimens for each dataset with associated posterior probabilities for $\mathrm{m} 1$ and $\mathrm{M} 3$.

\section{References}

Abramson, N.I., 1993. Evolutionary trends in the dentition of true lemmings (Lemmini, Cricetidae, Rodentia): functional-adaptive analysis. Journal of Zoology 230, 687-699. https://doi.org/10.1111/j.1469-7998.1993.tb02717.x

Abramson, N.I., Nadachowski, A., 2001. Revision of lemmings (Lemminae) from Poland with special reference of the occurrence of Synaptomys in Eurasia. Acta zoologica cracoviensia, 44(1), 65-77.https://doi.org/10.1111/j.1469-7998.1993.tb02717.x

Abramson, N.I., Petrova, T.V., 2018. Genetic analysis of type material of the Amur lemming resolves nomenclature issues and creates challenges for the taxonomy of true lemmings (Lemmus, Rodentia: Cricetidae) in the eastern Palearctic. Zoological Journal of the Linnean Society 182, 465-477. https://doi.org/10.1093/zoolinnean/zlx044 
Andersen, K.K., Azuma, N., Barnola, J.M., Bigler, M. et al., 2004. High-resolution record of Northern Hemisphere climate extending into the last interglacial period. Nature, 2004. v. 431, No. 7005. 147-151.

Batzli, G.O., Pitelka, F.A., 1983. Nutritional Ecology of Microtine Rodents: Food Habits of Lemmings near Barrow, Alaska. Journal of Mammalogy 64, 648-655. https://doi.org/10.2307/1380521

Baylac, M., Frieß, M., 2005. Fourier Descriptors, Procrustes Superimposition, and Data Dimensionality: An Example of Cranial Shape Analysis in Modern Human Populations, in: Slice, D.E. (Ed.), Modern Morphometrics in Physical Anthropology, Developments in Primatology: Progress and Prospects. Kluwer Academic Publishers-Plenum Publishers, New York, pp. 145-165. https://doi.org/10.1007/0-387-27614-9_6

Becker, A., Ammann, B., Anselmetti, F., Marie Hirt, A., Magny, M., Millet, L., Rachoud, A.M., Sampietro, G., Wûthrich, C., 2006. Paleoenvironmental studies on lake Bergsee, Black Forest, Germany. Neues Jahrbuch für Geologie und Paläontologie 240, 405-445.

Bennike, O., Houmark-Nielsen, M., Böcher, J., Heiberg, E.O., 1994. A multi-disciplinary macrofossil study of Middle Weichselian sediments at Kobbelgård, Møn, Denmark. Palaeogeography, Palaeoclimatology, Palaeoecology 11, 1-15. https://doi.org/10.1016/0031-0182(94)90344-1

Birks, H.H., Birks, H.J.B., 2014. To what extent did changes in July temperature influence Lateglacial vegetation patterns in NW Europe? Quaternary Science Reviews 106, 262277. https://doi.org/10.1016/j.quascirev.2014.06.024

Bobretsov, A.V., Lukyanova, L.E., 2017. Population dynamics of wood lemming (Myopus schisticolor) in different landscapes of the Northern Pre-Urals. Rus.J.Theriol. 16, 86-93. https://doi.org/10.15298/rusjtheriol.16.1.08

Bookstein, F.L., 1997. Morphometric Tools for Landmark Data: Geometry and Biology. Cambridge University Press.

Borodin, A.V., 2009. A Diagnostic Guide to Teeth of Arvicolines of the Urals and Western Siberia, from the Late Pleistocene to the Present. Ural Branch of the Russian Academy of Sciences Publishing, Yekaterinburg, 100 pp. (in Russian). 
650

651

652

653

654

655

656

657

658

659

660

661

662

663

664

665

666

667

668

669

670

671

672

673

674

675

676

677

678

Buzan, E.V., Krystufek, B., Hänfling, B., Hutchinson, W.F., 2008. Mitochondrial phylogeny of Arvicolinae using comprehensive taxonomic sampling yields new insights: Phylogeny of Arvicolinae. Biological Journal of the Linnean Society 94, 825-835. https://doi.org/10.1111/j.1095-8312.2008.01024.x

Calandra, I., Labonne, G., Mathieu, O., Henttonen, H., Lévêque, J., Milloux, M.-J., Renvoisé, É., Montuire, S., Navarro, N., 2015. Isotopic partitioning by small mammals in the subnivium. Ecol Evol 5, 4132-4140. https://doi.org/10.1002/ece3.1653

Chaline, J., Brunet-Lecomte, P., Brochet, G., Martin, F., 1989. Les lemmings fossiles du genre Lemmus (Arvicolidae, Rodentia)dans le pléistocène de France. Geobios 22, 613-623. https://doi.org/10.1016/S0016-6995(89)80115-9

Chaline, J., Brunet-Lecomte, P., Kaikusalo, A., Martin, F., Brochet, G., 1988. Discrimination de la morphologie dentaire de Lemmus lemmus et Myopus schisticolor (Arvicolidae, Rodentia) par l'analyse multivariée. Mammalia 52, 259-274. https://doi.org/10.1515/mamm.1988.52.2.259

Chaline, J., 1972. Les rongeurs du Pléistocène moyen et supérieur de France. Cahiers de Paléontologie, éd du CNRS, Paris, 410

Chaline, J., Mein, P., 1979, Les rongeurs et l'évolution. Doin, Paris, 235

Cheprakov, M.I., 2016. Встречаемость отложений цемента в терминальных синклиналях моляров у евразийских представителей трибы Lemmini (Rodentia, Arvicolinae). Зоол. ж. 95, 966-975.https://doi.org/10.7868/S0044513416060076

Cook, J.A., Runck, A.M., Conroy, C.J., 2004. Historical biogeography at the crossroads of the northern continents: molecular phylogenetics of red-backed voles (Rodentia: Arvicolinae). Molecular Phylogenetics and Evolution 30, 767-777. https://doi.org/10.1016/S1055$\underline{7903(03) 00248-3}$

Cox, P.G., Hautier, L., 2015. Evolution of the Rodents: Advances in Phylogeny, Functional Morphology and Development. Cambridge University Press.

Cucchi, T., Barnett, R., Martínková, N., Renaud, S., Renvoisé, E., Evin, A., Sheridan, A., Mainland, I., Wickham-Jones, C., Tougard, C., Quéré, J.P., Pascal, Michel, Pascal, Marine, Heckel, G., O’Higgins, P., Searle, J.B., Dobney, K.M., 2014. The changing pace of insular 
681

682

683

684

685

686

687

688

689

690

691

692

693

694

695

696

697

698

699

700

701

702

703

704

705

706

707

708

life: 5000 years of microevolution in the orkney vole (Microtus arvalis orcadensis). Evolution 68, 2804-2820. https://doi.org/10.1111/evo.12476

Currant, A.P., Jacobi, R., 2011. The Mammal Faunas of the British Late Pleistocene, in: Developments in Quaternary Sciences. Elsevier, pp. 165-180. https://doi.org/10.1016/B978-0-444-53597-9.00010-8

David, S., d'Errico, F., Pigeaud, R., Bereizat, G., Robert, E., Cailhol, D., Petrognani, S., Griggo, C., Jaillet, S., Jeannet, M., Paitiere, H., 2014. La grotte des Gorges ( Jura) : un site inédit à l'interface des territoires symboliques du Paléolithique supérieur ancien., in: Ricalens, M.O.\& F.L.B. (Ed.), Modes de Contacts et de Déplacements Au Paléolithique Eurasiatique.

David, S., Pigeaud, R., Battesti, D., Cailhol, D., Corbé, M., Ferrier, C., Paitier, H., Tirologos, G., Vuillermoz, D., 2017. L'art mobilier de la grotte des Gorges (Amange, Jura, France). Approche méthodologique et premiers résultats. in Cleyet-Merle J.-J., Geneste J.-M., ManEstier E. (dir.), L'art au quotidien - Objets ornés du Paléolithique supérieur. Actes du colloque international, Les Eyzies-de-Tayac, 16-20 juin 2014 PALEO, numéro spécial.

Delpech F., 1999. Biomasse d'Ongulés au Paléolithique et inférences sur la démographie. Paléo, $11,19-42$

Domine, F., Gauthier, G., Vionnet, V., Fauteux, D., Dumont, M., Barrere, M., 2018. Snow physical properties may be a significant determinant of lemming population dynamics in the high Arctic. Arctic Science 4, 813-826. https://doi.org/10.1139/as-2018-0008

Dryden, I.L. and Mardia, K.V., 1998. Statistical shape analysis, John Wiley and Sons, Chichester.

Duprat-Oualid, F., Rius, D., Bégeot, C., Magny, M., Millet, L., Wulf, S., Appelt, O., 2017. Vegetation response to abrupt climate changes in Western Europe from 45 to $14.7 \mathrm{k}$ cal a BP: the Bergsee lacustrine record (Black Forest, Germany). Journal of Quaternary Science 32, 1008-1021.https://doi.org/10.1002/jqs.2972

Escudé, E., Montuire, S., Desclaux, E., Quéré, J.-P., Renvoisé, E., Jeannet, M., 2008. Reappraisal of 'chronospecies' and the use of Arvicola (Rodentia, Mammalia) for biochronology. Journal of Archaeological Science 35, 1867-1879. https://doi.org/10.1016/j.jas.2007.11.018 
Eskelinen, O., 2002 Diet of the wood lemming Myopus schisticolor. Annales Zoologici Fennici vol. 39: 49-57.

Evin, A., Cucchi, T., Cardini, A., Strand Vidarsdottir, U., Larson, G., Dobney, K., 2013. The long and winding road: identifying pig domestication through molar size and shape. Journal of Archaeological Science 40, 735-743. https://doi.org/10.1016/j.jas.2012.08.005

Fejfar, O., Heinrich, W.-D., 1989. Muroid Rodent Biochronology of the Neogene and Quaternary in Europe, in: Lindsay, E.H., Fahlbusch, V., Mein, P. (Eds.), European Neogene Mammal Chronology, NATO ASI Series. Springer US, Boston, MA, pp. 91-117. https://doi.org/10.1007/978-1-4899-2513-8_7

Fletcher, W.J., Sánchez Goñi, M.F., Allen, J.R.M., Cheddadi, R., Combourieu-Nebout, N., Huntley, B., Lawson, I., Londeix, L., Magri, D., Margari, V., Müller, U.C., Naughton, F., Novenko, E., Roucoux, K., Tzedakis, P.C., 2010. Millennial-scale variability during the last glacial in vegetation records from Europe. Quaternary Science Reviews 29, 28392864. https://doi.org/10.1016/j.quascirev.2009.11.015

Freund D, 1998. Sesselfelsgrotte I: Grabungsverlauf und Stratigraphie., Saarbrïcken, Saarbrücker Dr. und Verl.

Gobalet, K.W., 2001. A Critique of Faunal Analysis; Inconsistency among Experts in Blind Tests. Journal of Archaeological Science 28, 377-386. https://doi.org/10.1006/jasc.2000.0564

Gromov, I.M., Polyakov, I.Y., 1992. Voles (Microtinae). Fauna of the USSR, mammals, Vol. 3, No 8 .

Harrison, D.L., Bates, P.J.J., Clayden, J.D., 1989. Occurrence of Lemmus kowalskii Carls and Rabeder, 1988 (Rodentia: Microtinae: Lemmus) in the Lower Pleistocene of East Anglia. Acta Theriol. 34, 55-65. https://doi.org/10.4098/AT.arch.89-3

Hernández Fernández, M., 2006. Rodent paleofaunas as indicators of climatic change in Europe during the last 125,000 years. Quat. res. 65, 308-323. https://doi.org/10.1016/j.yqres.2005.08.022

Hill, T.C.B., Woodland, W.A., Spencer, C.D., Marriott, S.B., Case, D.J., Catt, J.A., 2008. Devensian Late-glacial environmental change in the Gordano Valley, North Somerset, 
England: a rare archive for southwest Britain. J Paleolimnol 40, 431-444. https://doi.org/10.1007/s10933-007-9171-5

Horáček, I., Sánchez Marco, A., 1984. Comments on the Weichselian small mammal assemblages in Czechoslovakia and their stratigraphical interpretation. N. Jb. Geol. Paläont. Mh., 1984(9), 560-576. https://doi.org/10.1127/njgpm/1984/1984/560

Hulme-Beaman, Ardern, Cucchi, T., Evin, A., Searle, J.B., Dobney, K., 2018. Exploring Rattus praetor (Rodentia, Muridae) as a possible species complex using geometric morphometrics on dental morphology. Mammalian Biology 92, 62-67. https://doi.org/10.1016/j.mambio.2018.04.002

Huntley, B., Birks, H.J.B. 1983. An atlas of past and present pollen maps for Europe, 0-13,000 years ago. Cambridge University Press, 667

Jones, R.L., Keen, D.H., 2012. Pleistocene Environments in the British Isles. Springer Science \& Business Media, 368

Kaagan, L.M., 2000. The horse in late Pleistocene and Holocene Britain (Doctoral). Doctoral thesis, University of London. University of London, 432

Killick, L., 2012. Geometric Morphometric analysis of the Microtus M1 and its application to Early Middle Pleistocene in the UK. (Doctoral). Durham University, 393

Klein R.G., 1986. Carnivore size and quaternary climatic change in southern Africa. Quaternary Research, 26(1), 153-170

Klein R.G., Scott K., 1989. Glacial/interglacial size variation in fossil spotted hyenas (Crocuta crocuta) from Britain. Quaternary Research, 32(1), 88-95

Koenigswald, W., V., 1972. Sudmer-Berg-2, a fauna of the early middle Pleistocene from the Harz. Neues jahrbuch für Geologie und Palaontologie Abhandlungen, vol. 141, p. 194-221.

Koenigswald, W., V., Martin, L., D., 1984. Revision of the fossil and recent Lemminae (Rodentia, Mammalia). Papers in Vertebrate Paleontology honoring Robert Warren Wilson. Carnegie Museum of Natural History Special Publication, 9, 122-137

Kolendrianou, M., Ligkovanlis, S., Maniakas, I., Tzortzi, M., Iliopoulos, G., 2020. The Palaeolithic cave of Kalamakia (Mani Peninsula), Greece: new insights on the 
palaeoenvironment using microvertebrates and mesowear analysis of ruminant teeth. Heliyon 6, e03958. https://doi.org/10.1016/j.heliyon.2020.e03958

Kolfschoten, T.V., 1995. On the application of fossil mammals to the reconstruction of the palaeoenvironment of northwestern Europe. Acta zool. cracov. 38(1): 73-84

Kolfschoten, T.V., 1996. Mammalian remains in a Palaeolithic context. Archaeology, Methodology and the Organisation of Research. ABACO Edizioni, Forlih, 19-35.

Kovarovic, K., Aiello, L.C., Cardini, A., Lockwood, C.A., 2011. Discriminant function analyses in archaeology: are classification rates too good to be true? Journal of Archaeological Science 38, 3006-3018. https://doi.org/10.1016/j.jas.2011.06.028

Kowalski, K., 1977. Fossil lemmings [Mammalia, Rodentia] from the Pliocene and early Pleistocene of Poland. Acta zool. cracov. 22(7): 297-318

Kowalski, K., 1995. Lemmings [Mammalia, Rodentia] as indicators of temperature and humidity in the European Quaternary. Acta zool. cracov. 38(1): 85-94

Kowalski, K., 2001. Pleistocene rodents of Europe. Folia Quaternaria 72: 3-389.

Larsen, E., Mangerud, J., 1989. Marine caves: On-off signals for glaciations. Quaternary International 3-4, 13-19. https://doi.org/10.1016/1040-6182(89)90069-4

Le Vaillant, M., Erlandsson, R., Elmhagen, B., Hörnfeldt, B., Eide, N.E., Angerbjörn, A., 2018. Spatial distribution in Norwegian lemming Lemmus lemmus in relation to the phase of the cycle. Polar Biol 41, 1391-1403. https://doi.org/10.1007/s00300-018-2293-6

Lyman, R. L., 2002. Taxonomic identification of zooarchaeological remains, The Review of Archaeology, 23(2), 13-20

Lyman, R.L., 2019. Assumptions and Protocol of the Taxonomic Identification of Faunal Remains in Zooarchaeology: a North American Perspective. J Archaeol Method Theory 26, 1376-1438. https://doi.org/10.1007/s10816-019-09414-0

Markova, A.K., van Kolfschoten, T., Bohncke, S.J.P., Kosintsev, P.A., Mol, J., Puzachenko, A.Y., Simakova, A.N., Smirnov, N.G., Verpoorte, A., Golovachev, I.B., 2019. Institute of geography of Russian Academy of Sciences, 279.

Markova, E.A., Bobretsov, A.V., Starikov, V.P., Cheprakov, M.I., Borodin, A.V., 2018. Unification of Criteria for Distinguishing Morphotypes of Cheek Teeth in Lemmings 
(Lemmini, Arvicolinae, Rodentia). Biology Bulletin 45, 1083-1095. https://doi.org/10.1134/S106235901809011X

Marquet, J.-C., Lorblanchet, M., Oberlin, C., Thamo-Bozso, E., Aubry, T., 2016. Nouvelle datation du «masque » de La Roche-Cotard (Langeais, Indre-et-Loire, France). Paleo. Revue d'archéologie préhistorique 253-263. https://doi.org/10.4000/paleo.3144

Marr, M.M., 2016. Faunal response to abrupt climate change: the history of the British mammal fauna from the Lateglacial to the Holocene. Doctoral thesis, University of London, 375.

van der Meulen, A.J., 1973. Middle Pleistocene smaller mammals from the Monte Pegalia (Orvieto, Italy) with special reference to the phylogeny of Microtus (Arvicolidae, Rodentia), Quaternaria, vol. 17, 1-144.

McGuire, J.L., 2011. Identifying California Microtus species using geometric morphometrics documents Quaternary geographic range contractions. Journal of Mammalogy 92(6), 1383-1394. https://doi.org/10.1644/10-MAMM-A-280.1

Miele, V., Dussert, G., Cucchi, T., Renaud, S., 2020. Deep learning for species identification of modern and fossil rodent molars (preprint). Zoology. https://doi.org/10.1101/2020.08.20.259176

Mitchell-Jones, A. J., Amori, G., Bogdanowicz, W., Krystufek, B., Reijnders, P. J. H., Spitzenberger, F., Stubbe, M., Thissen, J. B. M., Voralik, V., \& Zima, J., 1999. The atlas of European mammals (Vol.3). London: Academic Press.

Monaghan, N.T., 2017. Irish Quaternary Vertebrates, in: Coxon, P., McCarron, S., Mitchell, F. (Eds.), Advances in Irish Quaternary Studies. Atlantis Press, Paris, pp. 255-291. https://doi.org/10.2991/978-94-6239-219-9_9

Montuire, S., Michaux, J., Legendre, S., Aguilar, J.-P., 1997. Rodents and climate. 1. A model for estimating past temperatures using arvicolids (Mammalia: Rodentia). Palaeogeography, Palaeoclimatology, Palaeoecology 128, 187-206. https://doi.org/10.1016/S0031-0182(96)00038-7

Montuire, S., Royer, A., Lemanik, A., Gilg, O., Sokolova, N., Sokolov, A., Desclaux, E., Nadachowski, A., Navarro, N., 2019. Molar shape differentiation during range expansions of the collared lemming (Dicrostonyx torquatus) related to past climate changes. 
Nadachowski, A., 1982. Late quaternary rodents of Poland with special reference to morphotype dentition analysis of voles. Państwowe Wydawnictwo Naukowe Warszawa, Kraków. 109

Navarro, N., Montuire, S., Laffont, R., Steimetz, E., Onofrei, C., Royer, A., 2018. Identifying Past Remains of Morphologically Similar Vole Species Using Molar Shapes. Quaternary 1, 20. https://doi.org/10.3390/quat1030020

Niethammer, J., \& Krapp, F., 1982. Handbuch der Säugetiere Europas. Band 2/I. Nagetiere II. Wiesbaden (DE): Akademische Verlagsgesellschaft.

Ognev, S.I., 1948. Mammals of the U.S.S.R and adjacent countries. Rodents. Israel Program for Scientific Translation, Jerusalem, 6: 354-461.

Pennington, W., Bertie, D.M., Mitchell, G.F., West, R.G., 1977. The Late Devensian flora and vegetation of Britain. Philosophical Transactions of the Royal Society of London. B, Biological Sciences 280, 247-271.https://doi.org/10.1098/rstb.1977.0109

Ponomarev, D., Puzachenko, A., Bachura, O., Kosintsev, P., van der Plicht, J., 2013a. Mammal fauna during the Late Pleistocene and Holocene in the far northeast of Europe: Late Pleistocene and Holocene mammal fauna, NE Europe. Boreas 42, 779-797. https://doi.org/10.1111/j.1502-3885.2012.00309.x

Ponomarev, D., Puzachenko, A., Isaychev, K., 2013b. Morphotypic variability of masticatory surface pattern of molars in the recent and Pleistocene Lemmus and Myopus (Rodentia, Cricetidae) of Europe and Western Siberia. Acta Zoologica 96, 14-29. https://doi.org/10.1111/azo.12047

Ponomarev, D., van Kolfschoten, T., van der Plicht, J., 2013c. Late Glacial and Holocene small mammals of the Timan Ridge (Komi Republic, Russia). Quaternary International 284, 177-183.https://doi.org/10.1016/j.quaint.2012.04.027

Price, C.R., 2003. Late Pleistocene and Early Holocene Small Mammals in South West Britain: Environmental and Taphonomic Implications and Their Role in Archaeological Research. Archaeopress. British archaeological reports: British series, vol. 347. 115. 
Prost, S., Klietmann, J., van Kolfschoten, T., Guralnick, R.P., Waltari, E., Vrieling, K., Stiller, M., Nagel, D., Rabeder, G., Hofreiter, M., Sommer, R.S., 2013. Effects of late quaternary climate change on Palearctic shrews. Glob Change Biol 19, 1865-1874. $\underline{\text { https://doi.org/10.1111/gcb.12153 }}$

Ramsey, C.B., Higham, T.F.G., Owen, D.C., Pike, A.W.G., Hedges, R.E.M., 2002. Radiocarbon Dates from the Oxford Ams System: Archaeometry Datelist 31. Archaeometry 44, 1-150. https://doi.org/10.1111/j.1475-4754.2002.tb01101.x

Reid, D.G., Bilodeau, F., Krebs, C.J., Gauthier, G., Kenney, A.J., Gilbert, B.S., Leung, M.C.Y., Duchesne, D., Hofer, E., 2012. Lemming winter habitat choice: a snow-fencing experiment. Oecologia 168, 935-946.https://doi.org/10.1007/s00442-011-2167-X

Reimer PJ, Bard E, Bayliss A, Beck JW, Blackwell PG, Bronk Ramsey C, Buck CE, Cheng H, Edwards RL, Friedrich M, Grootes PM, Guilderson TP, Haflidason H, Hajdas I, Hatté C, Heaton TJ, Hoffmann DL, Hogg AG, Hughen KA, Kaiser KF, Kromer B, Manning SW, Niu M, Reimer RW, Richards DA, Scott EM, Southon JR, Staff RA, Turney CSM, van der Plicht J. 2013. IntCal13 and Marine13 radiocarbon age calibration curves 0-50,000 years cal BP. Radiocarbon 55(4):1869-1887.

Rekovets, L.I., Kovalchuk, O.M., 2017. Phenomenon in the Evolution of Voles (Mammalia, Rodentia, Arvicolidae). Vestnik Zoologii 51, 99-110. https://doi.org/10.1515/vzoo-2017$\underline{0015}$

Rhodes, S.E., Ziegler, R., Starkovich, B.M., Conard, N.J., 2018. Small mammal taxonomy, taphonomy, and the paleoenvironmental record during the Middle and Upper Paleolithic at Geißenklösterle Cave (Ach Valley, southwestern Germany). Quaternary Science Reviews 185, 199-221. https://doi.org/10.1016/j.quascirev.2017.12.008

Robert, M.B., and Parfitt, S.A., 1999. Boxgrove, a Middle Pleistocene hominid site at Earthan Quarry, Boxgrove, West Sussex. English Heritage, Archaeological report 17, pp. 339

Robovský, J., Řičánková, V., Zrzavý, J., 2008. Phylogeny of Arvicolinae (Mammalia, Cricetidae): utility of morphological and molecular data sets in a recently radiating clade. Zoologica Scripta 37, 571-590. https://doi.org/10.1111/j.1463-6409.2008.00342.x

Rodgers, A.R., Lewis, M.C., 1986. Diet selection in Arctic lemmings ( Lemmus sibiricus and Dicrostonyx groenlandicus ): demography, home range, and habitat use. Canadian Journal of Zoology 64, 2717-2727. https://doi.org/10.1139/z86-396 
Rohlf, F.J., Slice, D., 1990. Extensions of the Procrustes Method for the Optimal Superimposition of Landmarks. Systematic Zoology 39, 40. https://doi.org/10.2307/2992207

Royer, A., 2013. Etude paléoenvironnementale et paléoclimatique du Pléistocène supérieur du Sud-Ouest de la France, à partir d'analyses comparées d'associations fauniques et de biogéochimies effectuées sur les micromammifères. Doctoral Thesis, Ecole Pratique des Hautes Etudes, 411.

Royer, A., 2016. How complex is the evolution of small mammal communities during the Late Glacial in southwest France ? Quaternary International 414, 23-33. https://doi.org/10.1016/j.quaint.2015.12.065

Royer, A., Montuire, S., Legendre, S., Discamps, E., Jeannet, M., Lécuyer, C., 2016. Investigating the Influence of Climate Changes on Rodent Communities at a RegionalScale (MIS 1-3, Southwestern France). PLOS ONE 11, e0145600. https://doi.org/10.1371/journal.pone.0145600

Royer, A., García Yelo, B.A., Laffont, R., Hernández Fernández, M., 2020. New bioclimatic models for the quaternary palaearctic based on insectivore and rodent communities. $\begin{array}{llll}\text { Palaeogeography, } \quad \text { Palaeoclimatology, } & \text { Palaeoecology } & 560, & 110040 .\end{array}$ https://doi.org/10.1016/j.palaeo.2020.110040

Smirnov, N.G., Golovachev, I.B., Kuznetsova, I.A., Cheprakov, M.I., 1997. Complicated cases of identifying rodent teeth from Late Pleistocene and Holocene deposits of tundra regions of Northern Eurasia. In: Kosintsev, P.A. (Ed.), Materialy Po Istorii I Sovremennomu Sostojaniju Fauny Severa Zapadnoj Sibiri: Sbornik Nauchnyh Trudov, 60e90. Riphey, Chelyabinsk (in Russian).

Stahl, P.W., 1996. The recovery and interpretation of microvertebrate bone assemblages from archaeological contexts. J Archaeol Method Theory 3, 31-75. https://doi.org/10.1007/BF02228930

Stenseth, N.C., Ims, R.A., 1993. Biology of lemmings. Published for the Linnean Society of London by Academic Press.

Stoetzel, E., Cornette, R., Lalis, A., Nicolas, V., Cucchi, T., Denys, C., 2017. Systematics and evolution of the Meriones shawii/grandis complex (Rodentia, Gerbillinae) during the Late Quaternary in northwestern Africa: Exploring the role of environmental and anthropogenic 
$\begin{array}{llll}\text { changes. } & \text { Quaternary } & \text { Science } & \text { Reviews }\end{array}$

917

918

919

920

921

922

923

924

925

926

927

928

929

930

931

932

933

934

Sutcliffe, A.J., Sutcliffe, A.J., Kowalski, K., 1976. Pleistocene rodents of the british isles. Bulletin of the British Museum (Natural History). 27, 31-147.

Tiunov, M.P., Panasenko, V.E., 2011. The distribution history of the Amur brown lemming (Lemmus amurensis) in the Late Pleistocene - Holocene in the southern Far East of Russia. Rus.J.Theriol. 9, 33-37. https://doi.org/10.15298/rusjtheriol.09.1.05

Walker, M.J.C., Coope, G.R., Sheldrick, C., Turney, C.S.M., Lowe, J.J., Blockley, S.P.E., Harkness, D.D., 2003. Devensian Lateglacial environmental changes in Britain: a multiproxy environmental record from Llanilid, South Wales, UK. Quaternary Science Reviews 22, 475-520. https://doi.org/10.1016/S0277-3791(02)00247-0

Wilson, D.E., Lacher, T.E., Mittermeier, R.A. (Eds.), 2017. Handbook of the Mammals of the World, vol. 7. Lynx Edicious, Barcelona. 1008. Rodent II.

Woodman, P., Mccarthy, M., Monaghan, N., 1997. The Irish quaternary fauna project. Quaternary Science Reviews 16, 129-159. https://doi.org/10.1016/S0277-3791(96)00037$\underline{6}$

Zelditch, M.L., Swiderski, D.L., Sheets, H.D., 2012. Introduction, in: Geometric Morphometrics for Biologists. Elsevier, pp. 1-20._https://doi.org/10.1016/B978-0-12$\underline{386903-6.00001-0}$ 


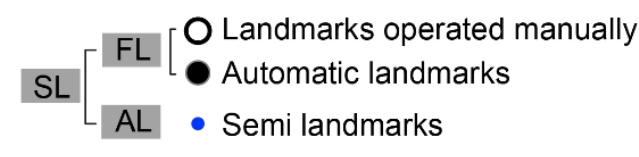

TL

First lower molar (right)
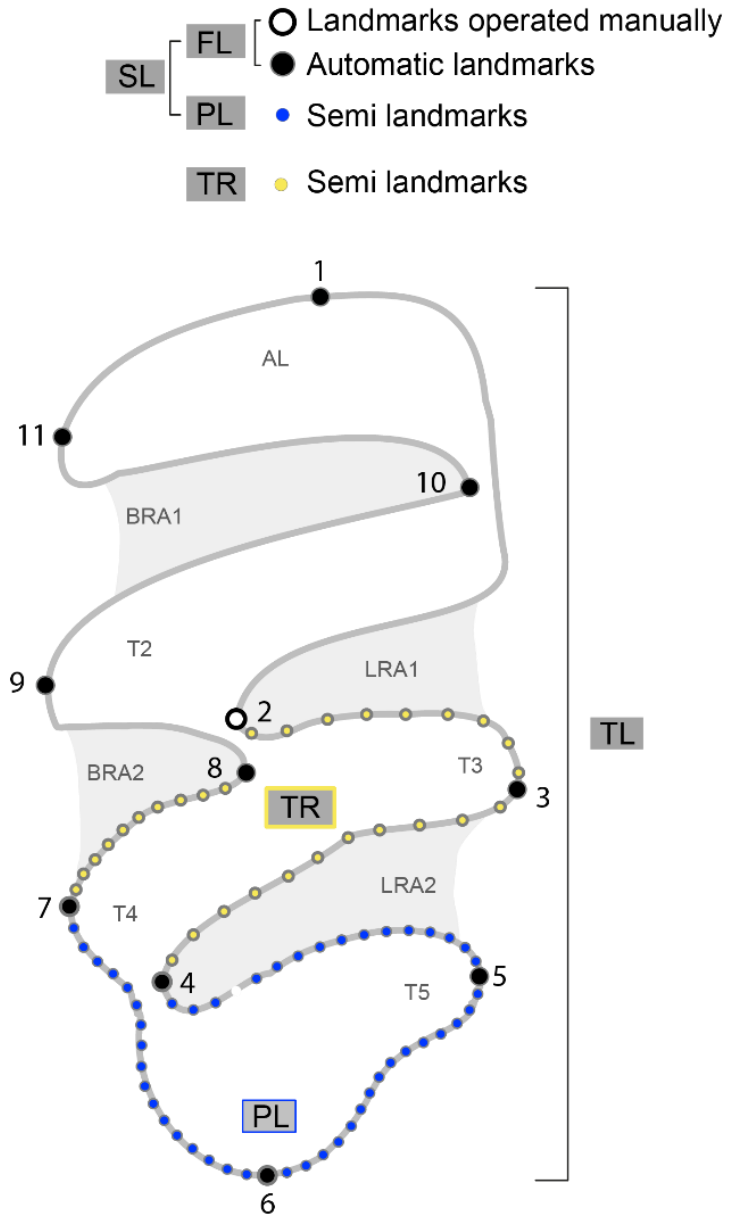

Third upper molar (right) 


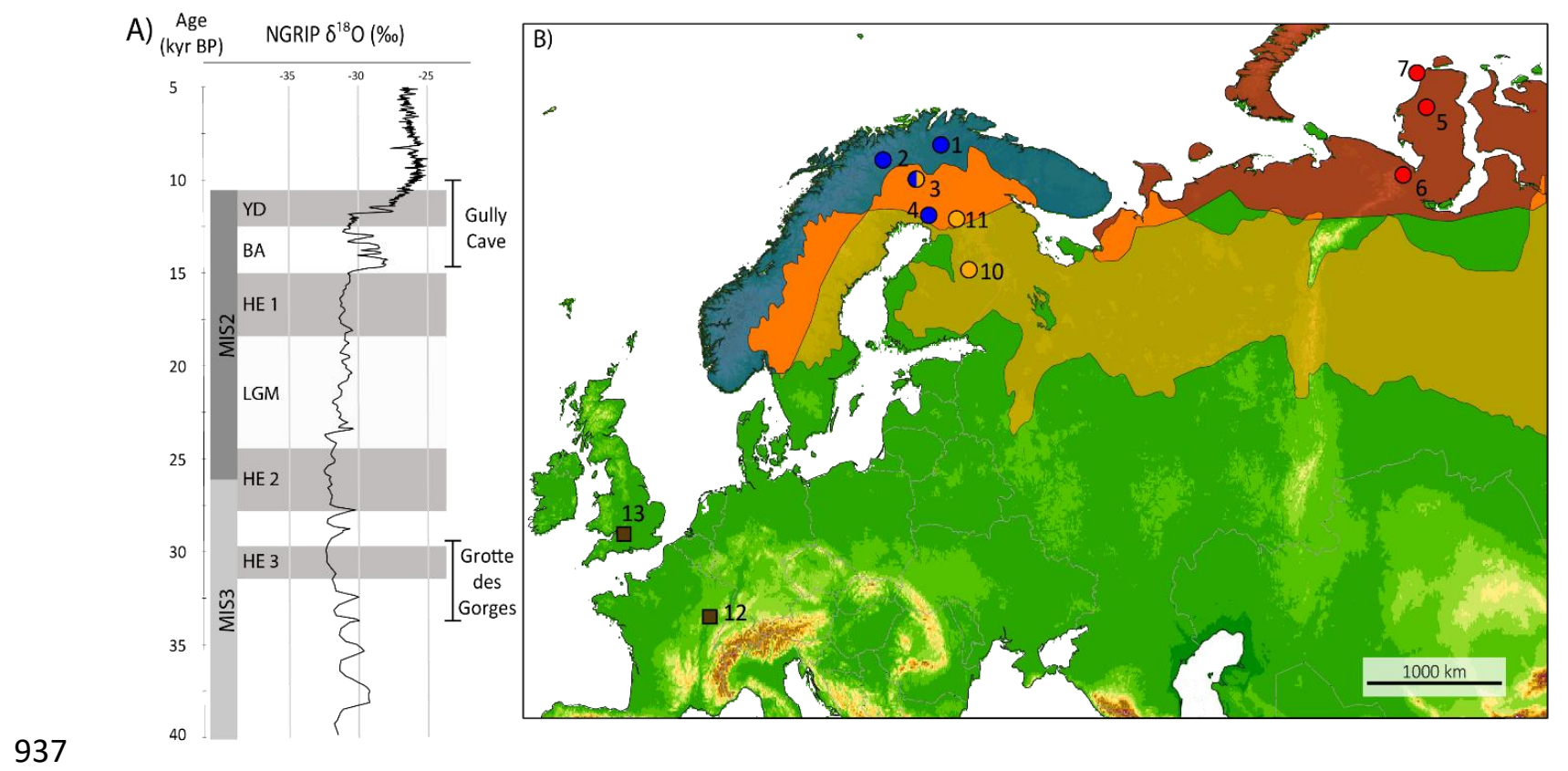

938 
$\checkmark$ Lemmus sibiricus

- Lemmus lemmus

$\checkmark$ Lemmus trimucronatus

$\diamond$ Myopus schisticolor
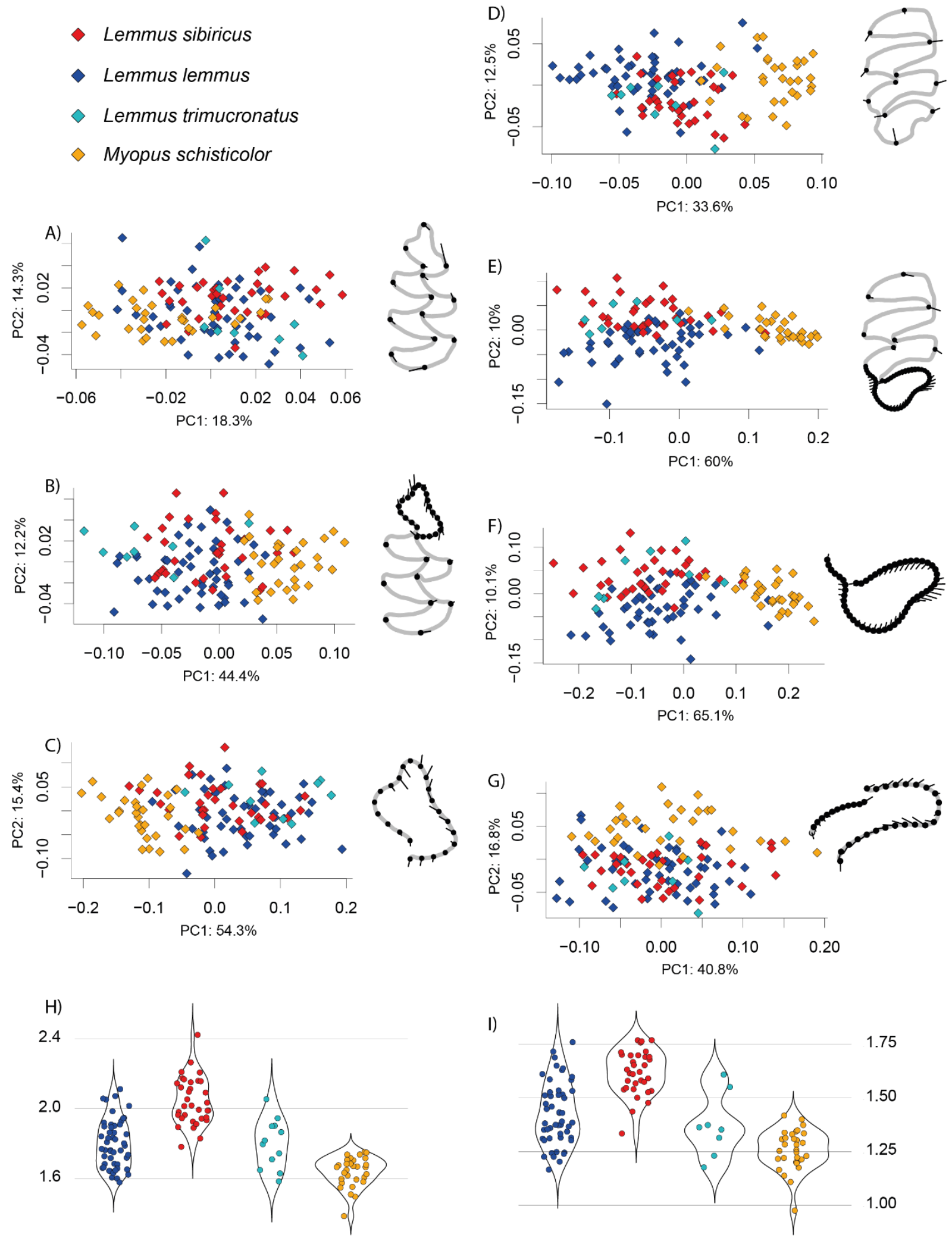

l)

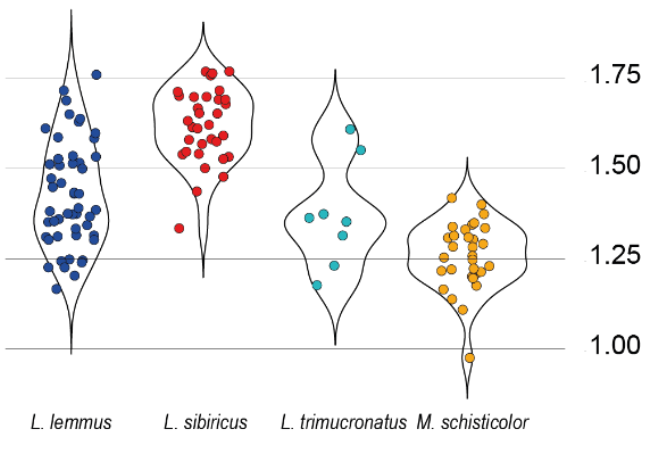
M3 

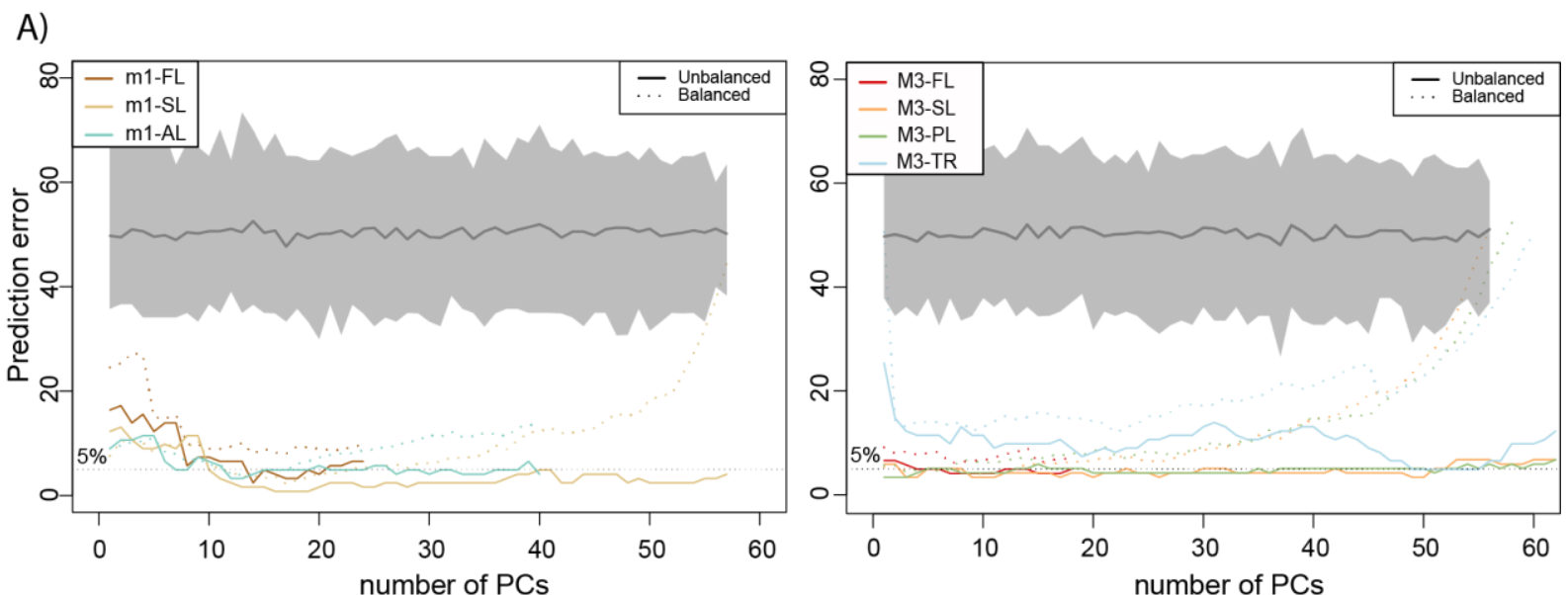

B)

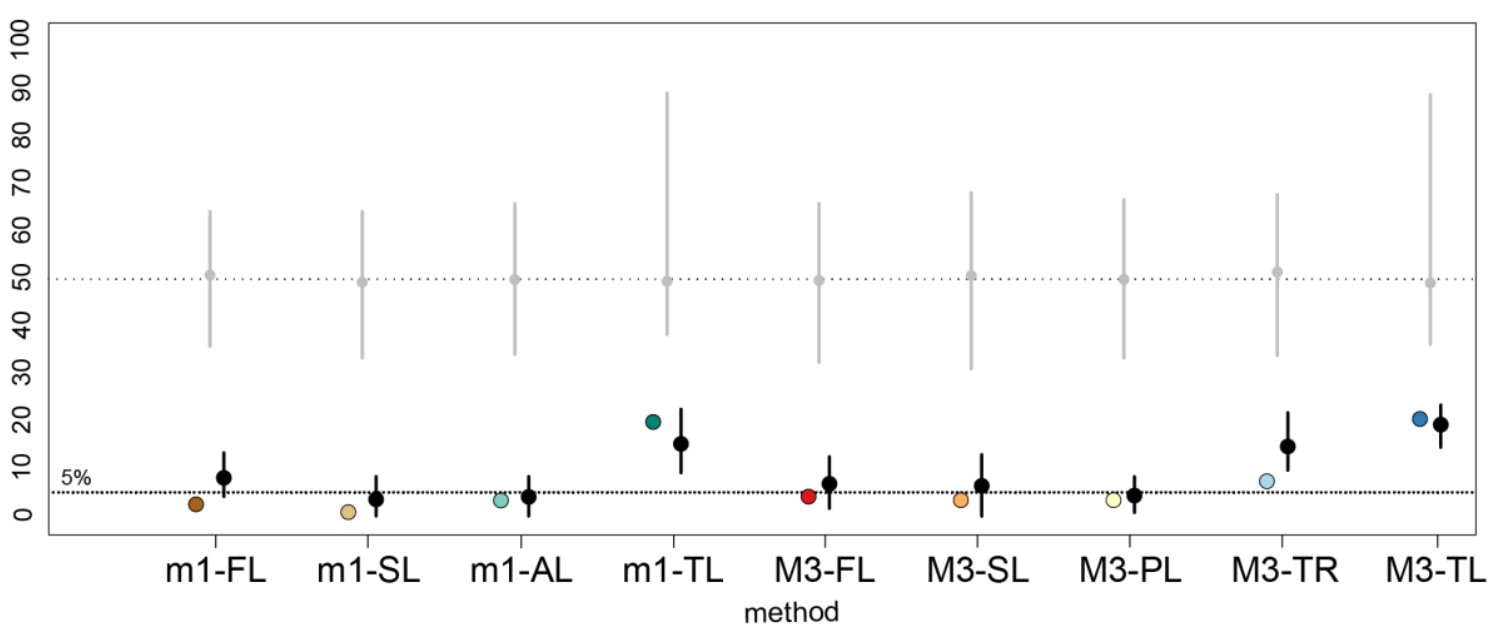

943

944 

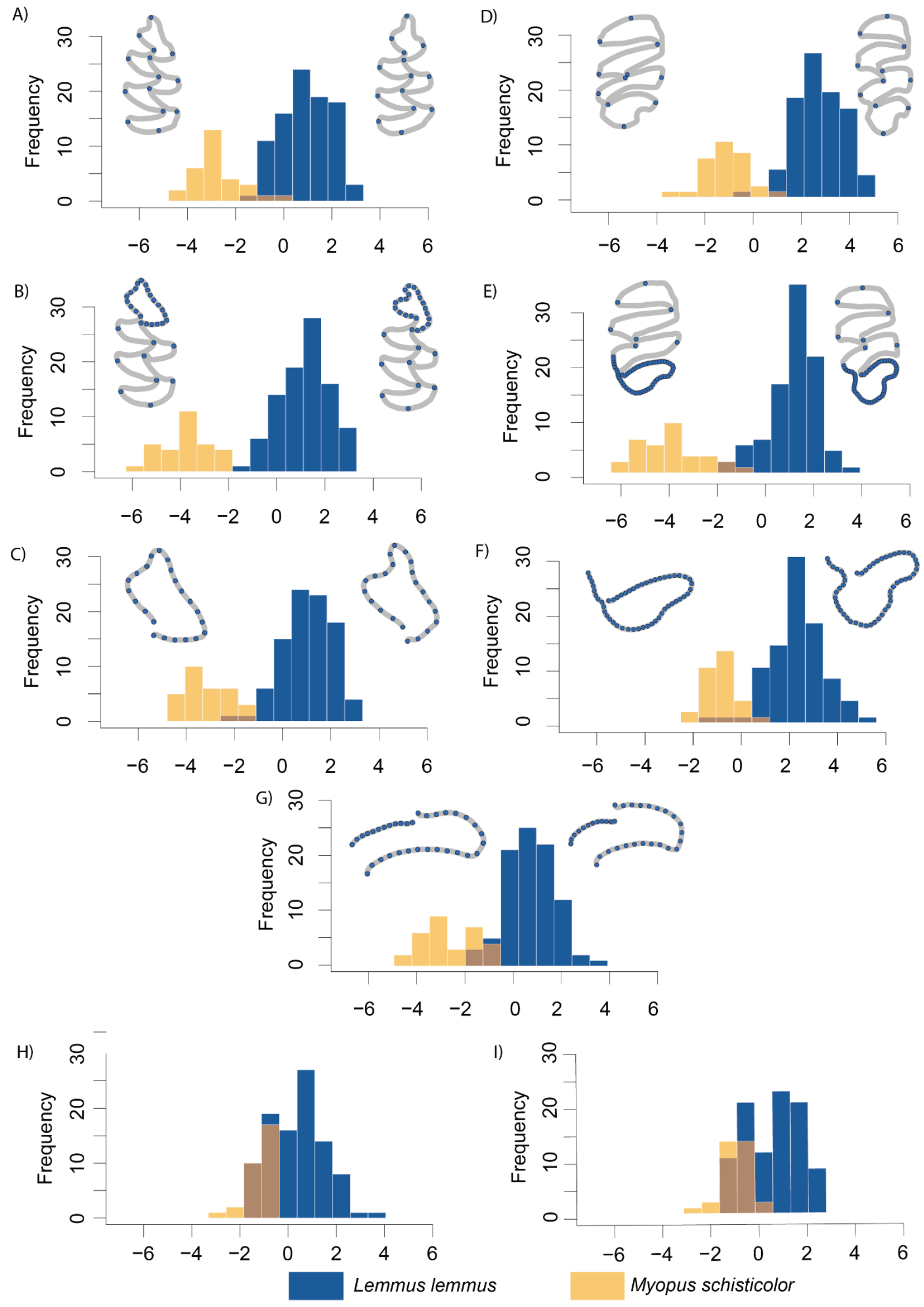

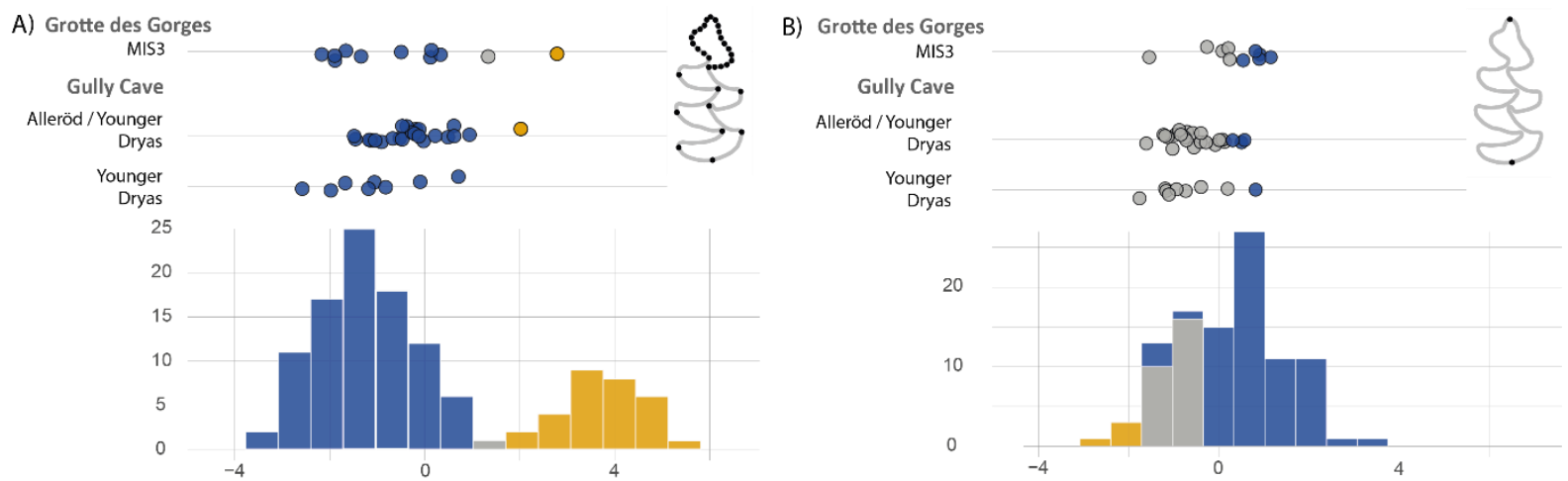

C) Grotte des Gorges

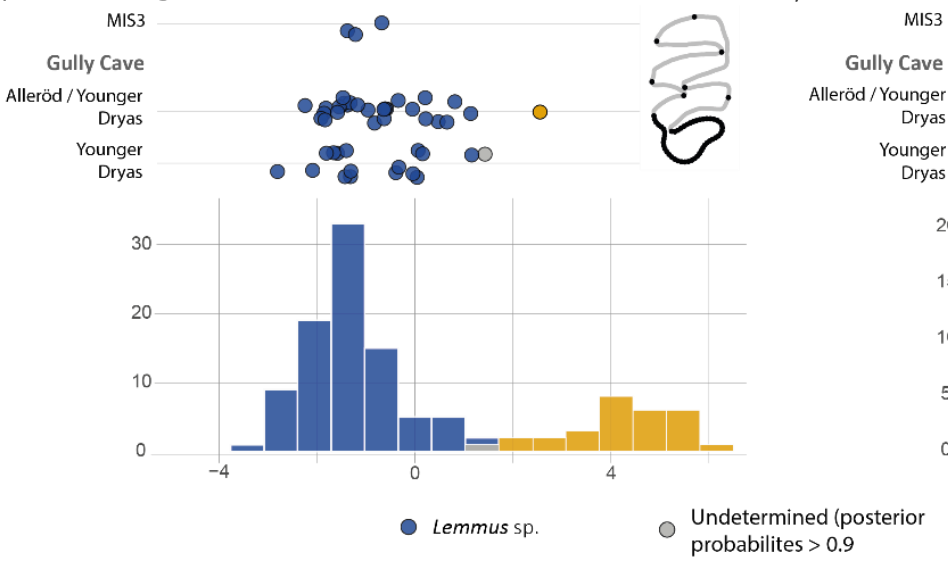

D) Grotte des Gorges
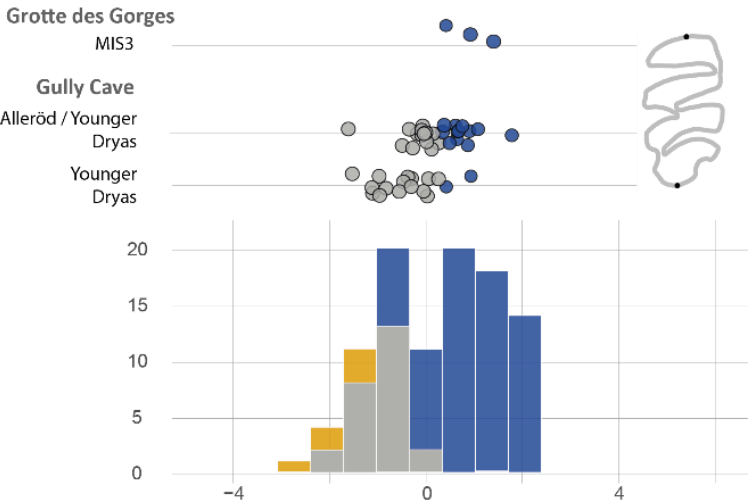

Myopus sp. 


\begin{tabular}{|c|c|c|c|c|}
\hline & Species & Location & Lower m1 & Upper M3 \\
\hline \multirow[t]{10}{*}{ Modern specimens } & \multirow[t]{4}{*}{ Lemmus lemmus (50) } & \multirow{4}{*}{$\begin{array}{l}\text { 1- Karigasniemi } \\
\text { 2- Kilpisjärvi } \\
\text { 3- Pallasjärvi, Muonio }\end{array}$} & 3 & 3 \\
\hline & & & 15 & 14 \\
\hline & & & 11 & 10 \\
\hline & & & 21 & 18 \\
\hline & \multirow[t]{4}{*}{ Lemmus sibiricus (34) } & \multirow{3}{*}{$\begin{array}{l}\text { 5- Sabetta } \\
\text { 6- Erkuta }\end{array}$} & 9 & 11 \\
\hline & & & 10 & 10 \\
\hline & & & 11 & 11 \\
\hline & & (8)- Wrangel Island & 4 & 1 \\
\hline & Lemmus trimucronatus (12) & (9)-Victoria Island & 12 & 8 \\
\hline & Myopus schisticolor (31) & 10-Sotkamo, Valtimo, Kuhmo, Lieka, & 20 & 21 \\
\hline
\end{tabular}




\begin{tabular}{|c|c|c|c|c|}
\hline & & 11-Posio & 1 & 1 \\
\hline & & (3)-Pallasjarvi, Muonio & 8 & 8 \\
\hline \multirow[t]{4}{*}{ Fossil specimens } & Amange & MIS3 & 11 & 3 \\
\hline & \multirow{3}{*}{$\begin{array}{l}\text { Gully Cave } \\
\text { (M3: 43; m1: 35) }\end{array}$} & Boundary Allerød / Younger Dryas & 23 & 26 \\
\hline & & Younger Dryas & 8 & 17 \\
\hline & & Younger Dryas? & 4 & 0 \\
\hline
\end{tabular}


Table 2: Datasets used in the present study. FL = Fixed landmarks, SL= Semi landmarks (including FL and AL for m1 and FL and PL for M3),

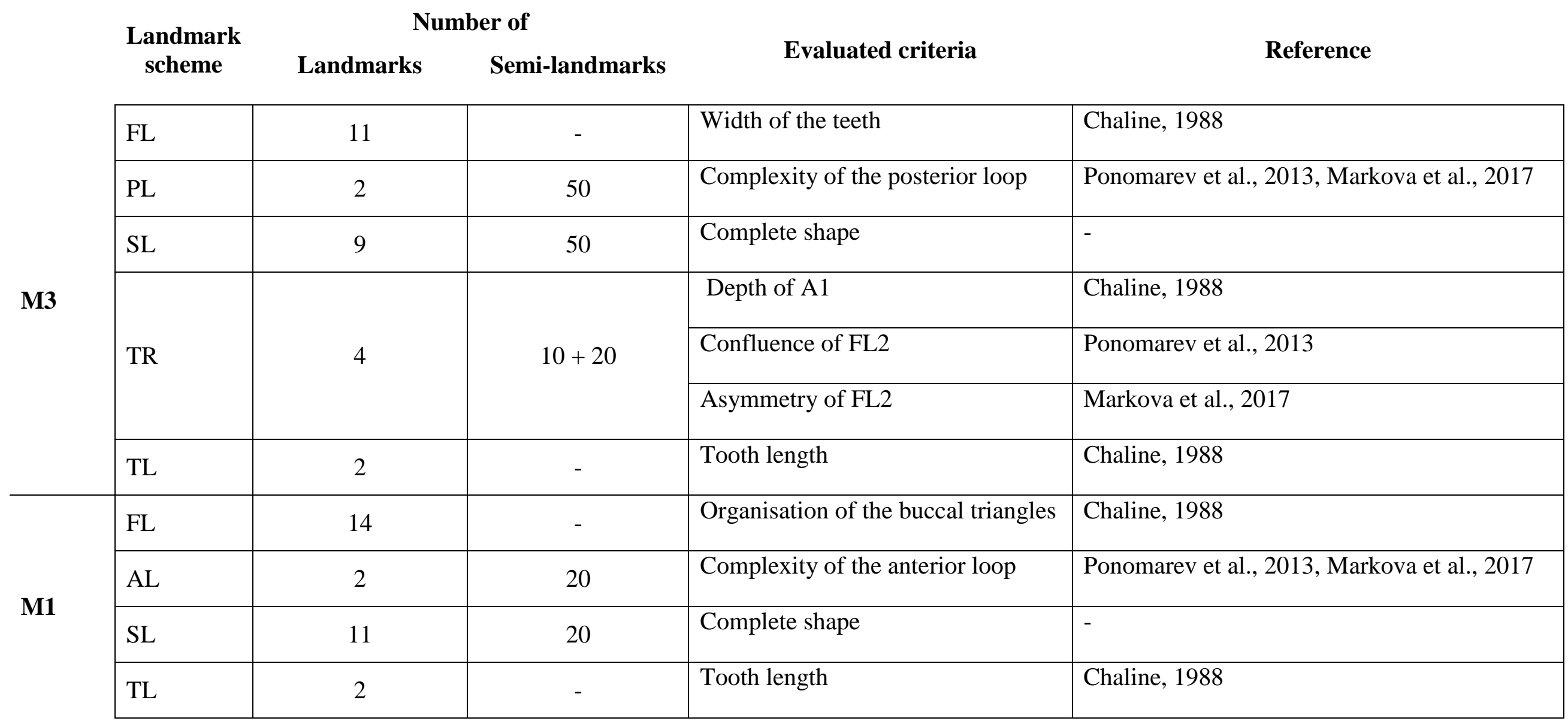



proportion of variance explained by PC1 + PC2, \% Opt. class. actual = percentage of prediction error of modern specimens with the optimal number of PCs (see text for details).

\begin{tabular}{|c|c|c|c|c|c|c|c|c|c|}
\hline & \multirow{2}{*}{ Dataset } & \multirow{2}{*}{ Tot. PCs } & \multirow{2}{*}{ Opt. PCs } & \multirow{2}{*}{$\mathbf{P C 1}+\mathbf{P C 2}$} & \multirow{2}{*}{$\begin{array}{c}\% \text { Pred. } \\
\text { Error }\end{array}$} & \multirow{2}{*}{$\begin{array}{c}\text { \% Opt. class. } \\
\text { actual }\end{array}$} & \multirow{2}{*}{$\begin{array}{c}\% \text { Opt. class. } \\
\text { fossil }\end{array}$} & \multicolumn{2}{|c|}{$\begin{array}{c}\text { Fossil } \\
\text { identification }\end{array}$} \\
\hline & & & & & & & & Lemmus & Myориs \\
\hline \multirow{4}{*}{ M1 } & FL & 28 & 14 & 32.6 & 2.5 & 85.5 & 80.4 & 38 & 8 \\
\hline & SL & 62 & 19 & 56.6 & 0.8 & 95.9 & 97.8 & 44 & 2 \\
\hline & $\mathrm{AL}$ & 44 & 12 & 69.6 & 3.3 & 93.4 & 71.7 & 27 & 19 \\
\hline & $\mathrm{TL}$ & - & - & - & 19.8 & 41.3 & 19.6 & 39 & 7 \\
\hline \multirow{5}{*}{ M3 } & FL & 18 & 17 & 46.1 & 4.1 & 89.3 & 80.4 & 36 & 1 \\
\hline & SL & 99 & 26 & 70 & 3.4 & 94.9 & 100 & 42 & 1 \\
\hline & PL & 92 & 3 & 75.7 & 3.4 & 88.1 & 65.2 & 22 & 1 \\
\hline & TR & 62 & 19 & 57.7 & 7.3 & 83.6 & 76.1 & 27 & 5 \\
\hline & TL & - & - & - & 20.5 & 41.8 & 34.8 & 13 & 5 \\
\hline
\end{tabular}




\begin{tabular}{|c|c|c|c|c|c|c|c|c|c|c|}
\hline & & $\mathrm{m} 1$ & & & & M3 & & & & \\
\hline & Lemmus & $12(12)$ & $12(12)$ & $9(2)$ & $9(0)$ & $15(15)$ & $17(16)$ & $15(10)$ & $16(1)$ & $14(2)$ \\
\hline & Lemmus & $17(10)$ & $22(22)$ & $10(9)$ & $20(3)$ & $24(19)$ & $25(25)$ & $16(9)$ & $23(19)$ & $25(12)$ \\
\hline Grotte des Gorges & Myopus & $2(2)$ & $1(1)$ & $3(3)$ & $1(0)$ & $0(0)$ & $0(0)$ & $0(0)$ & $0(0)$ & $0(0)$ \\
\hline & Lemmus & $9(9)$ & $10(9)$ & $8(7)$ & $10(6)$ & $3(2)$ & $3(3)$ & $3(3)$ & $3(3)$ & $3(3)$ \\
\hline
\end{tabular}

